\title{
Antibody-Derived In Vivo Imaging of Tau Pathology
}

\author{
Senthilkumar Krishnaswamy, ${ }^{1}$ Yan Lin, ${ }^{1}$ Wajitha J. Rajamohamedsait, ${ }^{1}$ Hameetha B. Rajamohamedsait, ${ }^{1}$ \\ Pavan Krishnamurthy, ${ }^{1}$ and Einar M. Sigurdsson ${ }^{1,2}$ \\ ${ }^{1}$ Department of Neuroscience and Physiology and ${ }^{2}$ Department of Psychiatry, New York University School of Medicine, New York, New York 10016
}

\begin{abstract}
Antibodies or their derivatives as imaging probes for pathological tau protein have great potential, but have not been well studied. In particular, smaller, single-chain-variable antibody fragments (scFv's) are attractive for detecting tau lesions in live subjects. Here, we generated libraries of scFv's and identified numerous phospho-tau-selective scFv's. Peripheral injection of one of these scFv's consistently resulted in a strong in vivo brain signal in transgenic tauopathy mice, but not in wild-type or amyloid- $\beta$ plaque mice. The parent tau antibody provided similar results, albeit with a weaker signal intensity. The imaging signal correlated very well with colocalization of the probe with intraneuronal tau aggregates. Both were associated with markers of endosomes, autophagosomes, and lysosomes, suggesting their interaction in these degradation pathways. Such specific antibody-derived imaging probes have great potential as diagnostic markers for Alzheimer's disease and related tauopathies.
\end{abstract}

Key words: Alzheimer's disease; diagnosis; imaging; IVIS; scFv; tau

\section{Introduction}

Dire need exists for accurate diagnosis of Alzheimer's disease (AD) and other tauopathies in live subjects and to monitor efficacy of treatments targeting various forms of pathological tau proteins. Antibody detection of abnormal tau in CSF has shown some promise in $\mathrm{AD}$ patients (Blennow et al., 2010; Weiner et al., 2013) and several tau-targeting dyes are in preclinical and some in clinical development as imaging agents (Okamura et al., 2005; Fodero-Tavoletti et al., 2011; Ono et al., 2011; Zhang et al., 2012; Chien et al., 2013; Harada et al., 2013; Maruyama et al., 2013; Xia et al., 2013; Chien et al., 2014; Fodero-Tavoletti et al., 2014; Okamura et al., 2014; Villemagne et al., 2014). However, CSF tau levels in tauopathies other than $\mathrm{AD}$ are usually not altered compared with controls (Hales and $\mathrm{Hu}, 2013$ ) and preliminary clinical data indicate that the imaging dyes may not detect pathological tau in all tauopathies (Fodero-Tavoletti et al., 2014). Therefore, alternative approaches are needed. Imaging these tau lesions in concert with amyloid- $\beta(\mathrm{A} \beta)$ is more likely to lead to accurate diagnosis because the regional pattern of tau aggregates differs between the different tauopathies. Furthermore, all of

Received July 7, 2014; revised Oct. 3, 2014; accepted Nov. 3, 2014.

Author contributions: E.M.S. designed research; S.K., Y.L., W.J.R., H.B.R., and P.K. performed research; S.K. and E.M.S. analyzed data; S.K. and E.M.S. wrote the paper.

This work was supported by the National Institutes of Health (NIH Grants NS077239, AG032611, and AG020197). Human brain tissue was obtained from the National Disease Research Interchange, which is supported by NIH grants. NYU technology on tau immunotherapy is licensed to and is being codeveloped with $\mathrm{H}$. Lundbeck $\mathrm{A} / \mathrm{S}$. We thank Peter Davies (Albert Einstein College of Medicine and Long Island Jewish Medical Center) for the tau antibodies, PHF1, MC1, and CP27, which were used for immunohistochemistry and/or Western blots; Carlos Barbas (Scripps Research Institute) for the pComb3XSS phagemid vector; Yan Deng at the NYULMC microscopy core for his advice and assistance with confocal imaging and related analysis; and Jan T. Pedersen and Jeffrey Stavenhagen (H. Lundbeck A/S) for their comments.

E.M.S. is an inventor on relevant diagnostic patents assigned to NYU and licensed to H. Lundbeck A/S.

Correspondence should be addressed to Einar M. Sigurdsson, PhD, Associate Professor, Department of Neuroscience and Physiology, New York University School of Medicine, 550 First Avenue, Medical Science Building, Room MSB459, New York, NY 10016. E-mail: Einar.Sigurdsson@nyumc.org.

DOI:10.1523/JNEUROSCI.2755-14.2014

Copyright $\odot 2014$ the authors $\quad 0270-6474 / 14 / 3416835-16 \$ 15.00 / 0$ them except $\mathrm{AD}$ are in part defined by lack of $\mathrm{A} \beta$ deposition. In vivo imaging of extracellular $\mathrm{A} \beta$ plaques using compounds that bind well to $\beta$-sheets is already in clinical use (Mason et al., 2013), but the path forward for tau ligands is not as clear because tau aggregates are mainly found within neurons. Therefore, tau diagnostic imaging ligands need not only to be able to cross the blood-brain barrier (BBB), but have to be taken up into neurons for maximal efficacy. This is particularly the case in the early stages of pathology when extracellular tangles are rare.

Antibody-based probes such as those proposed here are likely to provide greater specificity than $\beta$-sheet dyes for detecting tau lesions in patients with $\mathrm{AD}$ or other tauopathies. In particular, smaller antibody fragments that bind to tau are attractive as ligands for in vivo imaging. Their smaller size compared with antibodies may lead to better access to tau aggregates. Another advantage is their relatively rapid clearance from the circulation compared with unmodified antibodies that have longer halflives. Within the cancer field, therapeutic antibodies have routinely been codeveloped as imaging agents and several such antibodies and Fab fragments are FDA approved for tumor imaging (Kaur et al., 2012). In the near future, these will likely be replaced with smaller diabodies and scFv's with better pharmacokinetic properties as imaging agents (Olafsen and $\mathrm{Wu}, 2010$; Kaur et al., 2012).

In this study, we generated, using phage-display technology, numerous scFv's of a monoclonal tau antibody that we developed previously (Congdon et al., 2013; Gu et al., 2013). After extensive characterization, a lead $\mathrm{scFv}$ with the desired properties was assessed as a diagnostic imaging probe in live tauopathy mice.

\section{Materials and Methods}

Materials. The following materials were used for $\mathrm{scFv}$ generation, scaleup, and labeling: Hybridoma clone 6B2G12 (raised against P-Ser396/404 of the tau protein) generated by a subcontractor (Genscript); pComb3XSS phagemid vector (Barbas laboratory, Scripps Research Institute); E. coli strains ER2537 (New England Biolabs) and TOP10 (In- 
a

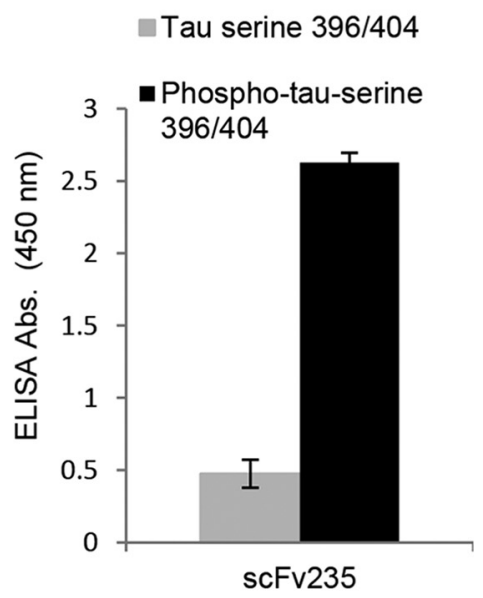

C

\section{scFv235}

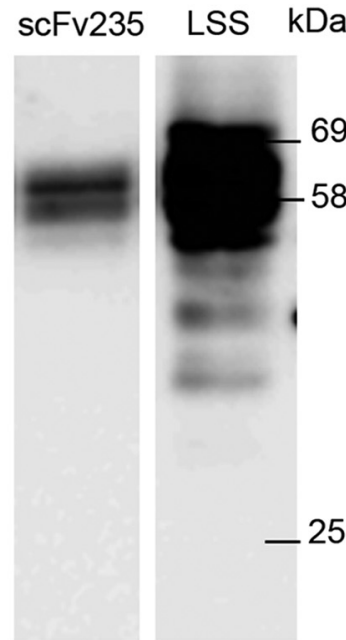

human tau

\begin{tabular}{|c|c|c|c|c|c|c|}
\hline & \multicolumn{2}{|c|}{ Association (1/Ms) } & \multicolumn{2}{|c|}{ Dissociation (1/S) } & \multicolumn{2}{c|}{$K_{\mathrm{D}}(\mathrm{M})$} \\
\hline Analyte/Peptides & $6 \mathrm{~B} 2 \mathrm{G} 12$ & scFv235 & $6 \mathrm{~B} 2 \mathrm{G12}$ & scFv235 & $6 \mathrm{~B} 2 \mathrm{G12}$ & scFv235 \\
\hline $\begin{array}{c}\text { Phospho-tau- } \\
\text { serine 396/404 }\end{array}$ & $3.69 \times 10^{6}$ & $3.93 \times 10^{3}$ & $1.46 \times 10^{-3}$ & $3.9 \times 10^{-3}$ & $3.95 \times 10^{-10}$ & $9.94 \times 10^{-7}$ \\
\hline $\begin{array}{c}\text { Tau-serine } \\
396 / 404\end{array}$ & $1.16 \times 10^{6}$ & 9.74 & $2.92 \times 10^{-3}$ & 0.0396 & $2.51 \times 10^{-9}$ & $4.06 \times 10^{-3}$ \\
\hline
\end{tabular}

d

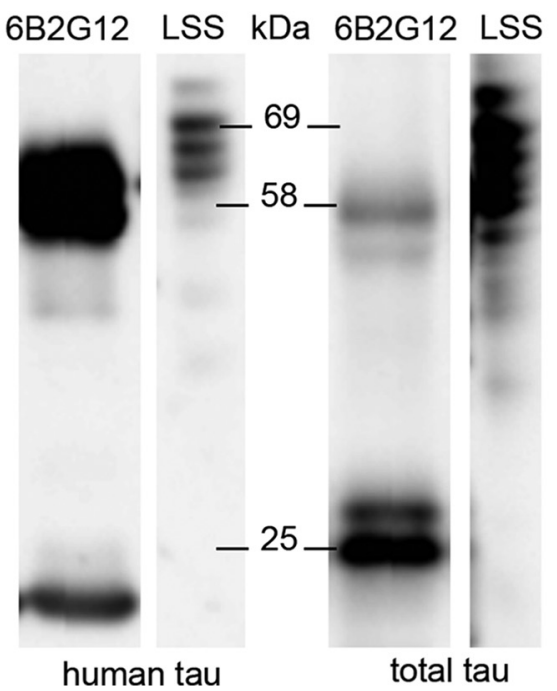

Figure 1. scFv235 binds selectively to phospho-tau epitope and to tau protein in Alzheimer's brain homogenate. $\boldsymbol{a}$, scFv235 selectively binds to the phospho-tau-serine 396/404 (P-Ser396/404) epitope in ELISA compared with its non-phospho equivalent epitope (Ser396/404). $\boldsymbol{b}$, The parent antibody 6B2G12 has $\sim 400$ times higher affinity for the P-Ser396/404 peptide than scFv235 and $\sim 600,000$ times higher affinity for Ser396/404 than scFv235. Therefore, scFv235 is much more phospho-selective. $K_{\mathrm{D}}$ (dissociation constant) $=k_{\text {off }}$ (dissociation) $/ k_{\text {on }}$ (association). $c$, scFv235 pulls down tau in AD brain homogenate. Immunoprecipitation of AD brain homogenate with scFv235 pulled down tau bands in the range of $50-70$ kDa. Western blots with CP27 (human tau) and polyclonal total tau antibody (Dako) showed similar results with no other bands detected. For comparison, low speed supernatant (LSS) of the brain homogenate is in adjacent lane from the same blot with several additional tau-positive bands. $\boldsymbol{d}, 6 \mathrm{~B} 2 \mathrm{G} 12$ pulls down tau in AD brain homogenate. Immunoprecipitation of AD brain homogenate with 6B2G12 pulled down tau bands in the range of $50-70 \mathrm{kDa}$, as well as degradation fragments 20-30 kDa. Western blots with CP27 (human tau) and polyclonal total tau antibody (Dako) showed greater detection of intact tau with CP27 and smaller tau fragments with Dako tau. For comparison, LSS of the brain homogenate is in adjacent lane from the same blot with several additional tau-positive bands.

vitrogen); first-strand cDNA synthesis kit (Takara), RNA isolation kit (Promega), DNA ligase, SfiI restriction enzyme, VCSM13 helper phage, and carbenicillin sodium (Thermo Fisher Scientific); Ni-NTA Agarose (Qiagen), Alexa Fluor 568 kit (Invitrogen) and VivoTag 680 XL Fluorochrome (PerkinElmer), Tau-serine 396/404 (RENAKAKTDHGAEIVYK [Ser]PVVSGDT[Ser]PRHL) and Tau-phospho-serine 396/404 (RENAK AKTDHGAEIVYK[P-Ser]PVVSGDT[P-Ser]PRHL) peptides (Keck Foundation, Yale University) were used for panning, ELISA and in Biacore for binding studies. Secondary antibodies for scFv were HRPconjugated anti HA (Roche). Dynabeads His-Tag and protein G pulldown kit (Life Technologies) were used for immunoprecipitation. Primary antibodies PHF1, MC1, and CP27 (generous gift from Dr. Peter Davies, Albert Einstein College of Medicine, Bronx, NY), Tau5 (Thermo Fisher Sci), polyclonal total tau antibody (Dako), LC3 (Novus Biologicals), EEA1, P62, and Rab7 (Cell Signaling Technology), and Ibal (Wako) were used for immunohistochemistry and/or Western analysis.
scFv library preparation. $\mathrm{scFv}$ was performed following the protocol detailed in Phage Display: A Laboratory Manual (Barbas et al., 2001) Briefly, the hybridoma cell line $6 \mathrm{~B} 2 \mathrm{G} 12$ was grown at $37^{\circ} \mathrm{C}$ with $5 \% \mathrm{CO}_{2}$ in RPMI medium containing streptomycin $(50 \mu \mathrm{g} / \mathrm{ml})$ and penicillin $\mathrm{G}$ $(50 \mathrm{U} / \mathrm{ml})$ and its mRNA was isolated and purified as per the kit protocol (Promega) and stored at $-80^{\circ} \mathrm{C}$. The first-strand cDNA was constructed as per the Takara kit (TAK6115A). The variable heavy and light chain (combination of $\mathrm{V} \lambda$ and $\mathrm{V} \kappa$ ) were amplified from cDNA using the primers listed in the manual. Variable regions were linked with linker $\left(\mathrm{V}_{\mathrm{L}^{-}}\right.$ Linker- $\left.\mathrm{V}_{\mathrm{H}}\right)$. The linked variable product was then ligated into phagemid vector pComb3XSS and transformed into ER2537 E. coli cells to obtain scFv library. The library was infected with helper phage and panned against the tau-phospho-serine 396/404 and tau-serine 396/404 peptides. From the panning-enriched clones, several highly positive clones were obtained against tau-phospho-serine 396/404. From those clones, scFv235 was selected for further study. The scFv's contain His and HA tags to facilitate detection/purification. 

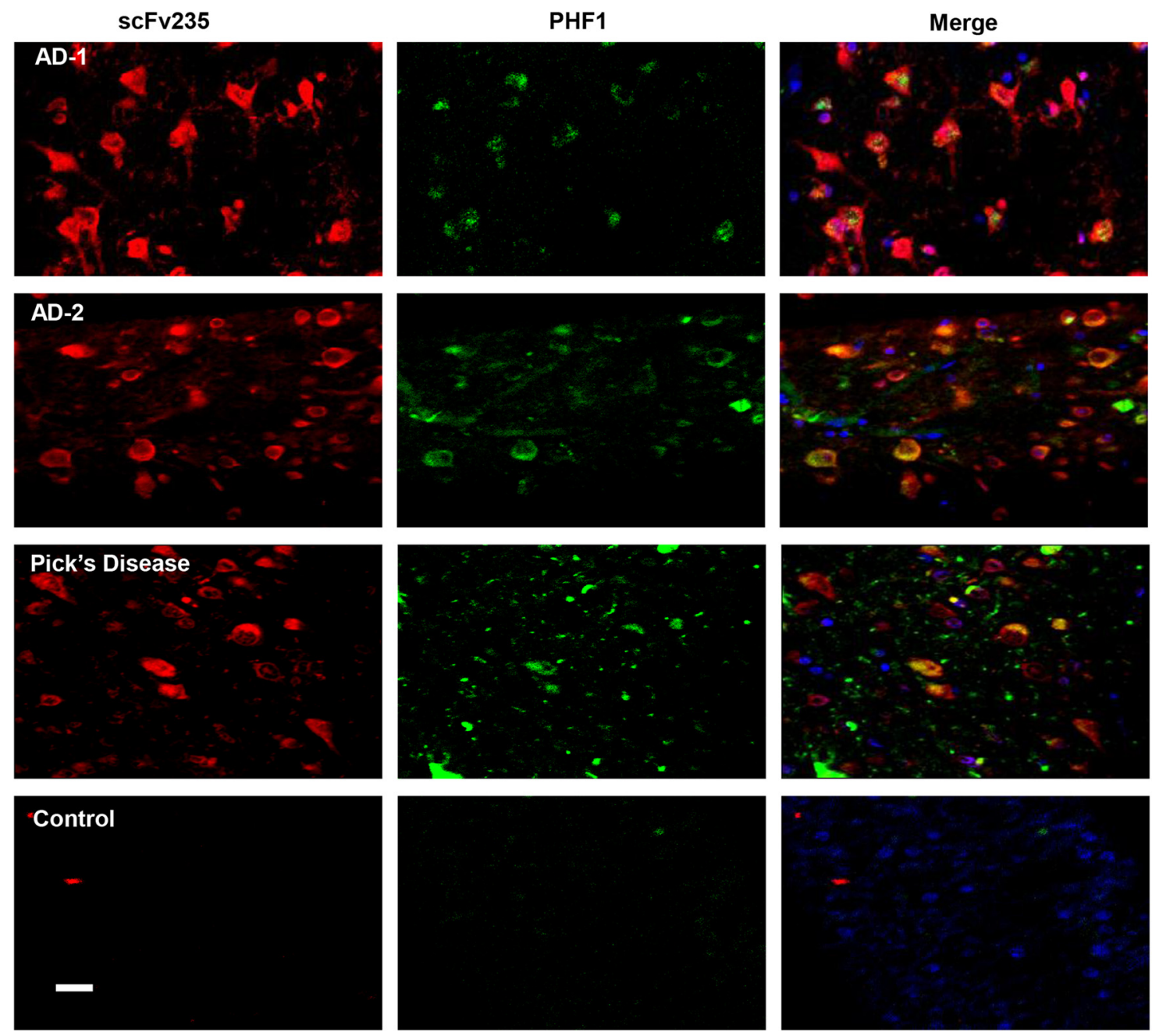

Figure 2. scFv235 stains brain tau pathology in human tissue. Staining of human Alzheimer's and Pick's disease brain sections with scFv235 (red) revealed extensive neuronal staining that showed partial colocalization (yellow) with PHF1 staining (green). Very limited staining was observed in control human tissue. Nuclei were stained with Hoechst (blue). Scale bar, $20 \mu \mathrm{m}$. AD-1 and AD-2 are brain sections from different Alzheimer's cases.

Production of soluble antibodies. The production of soluble antibodies was performed as described previously (Barbas et al., 2001). Briefly, scFv235 was produced in competent nonsuppressor E. coli cells (top 10 cells) in super broth medium (10 $\mathrm{g}$ of MOPS, $30 \mathrm{~g}$ of tryptone, $20 \mathrm{~g}$ of yeast extract per liter) with $50 \mu \mathrm{g} / \mathrm{ml}$ carbenicillin and $20 \mathrm{ml}$ of $1 \mathrm{M} \mathrm{MgCl}_{2}$ per L. The culture was induced by adding $1 \mathrm{~mm}$ isopropyl- $\beta$-Dthiogalactoside and scFv235 was isolated from the pellet as described previously (Barbas et al., 2001).

Characterization of scFv235. The His-tagged scFv235 was purified using Ni-NTA agarose resin loaded in a gravity column, following the Qiagen kit protocol. The antibody fragment was then dialyzed in PBS and used for further characterization. Phosphoselectivity of the purified scFv was first confirmed in an ELISA assay as described previously (Asuni et al., 2007). Briefly, tau-phospho-serine 396/404 and tau serine 396/404 peptides were coated onto the plate overnight at $4^{\circ} \mathrm{C}$ and, after blocking, were incubated with $2.5 \mu \mathrm{g}$ of scFv235 for $2 \mathrm{~h}$. HRP-conjugated anti-HA secondary antibody was used to detect bound scFv235 at $450 \mathrm{~nm}$.

Surface plasmon resonance analysis. The binding kinetics of scFv235 and the parent antibody, $6 \mathrm{~B} 2 \mathrm{G} 12$, to their target molecules were measured by surface plasmon resonance analysis in a Biacore 2000 (GE Healthcare) according to the manufacturer's instructions and as described previously (Krishnaswamy et al., 2009; Krishnaswamy et al., 2011). Briefly, scFv235/antibody $(10 \mu \mathrm{g} / \mathrm{ml})$ was diluted in $10 \mathrm{~mm}$ sodium acetate, $\mathrm{pH}$ 5.0, and immobilized on a separate CM5 sensor chip with an amine coupling kit ( $7 \mathrm{~min}$ contact time at $5 \mu \mathrm{l} / \mathrm{min}$ flow rate). Unreacted surface-bound material was blocked with ethanolamine. One channel of each sensor chip, prepared in the same way without scFv235 or antibody, was used to monitor the nonspecific binding of the peptide. All measurements were done with HBS-EP buffer (10 mM HEPES, $\mathrm{pH}$ 7.4, $150 \mathrm{~mm} \mathrm{NaCl}, 3.4 \mathrm{~mm}$ EDTA, and $0.005 \%$ surfactant P20) at flow rate of $5 \mu \mathrm{l} / \mathrm{min}$ at $25^{\circ} \mathrm{C}$. After each measurement, the chip surface was regenerated with $10 \mu \mathrm{l}$ of a buffer containing $500 \mathrm{~mm} \mathrm{NaCl}$ and $0.1 \mathrm{M}$ glycine $\mathrm{HCl}, \mathrm{pH}$ 8.0. Binding of tau-phospho-serine 396/404 and tau-serine 396/ 404 peptides was determined at various concentrations and the equilibrium dissociation constant $\left(K_{\mathrm{d}}\right)$ was calculated using BIAevaluation software with $K_{\mathrm{d}}=k_{\text {off }} / k_{\text {on }}$.

Immunoprecipitation. Dynabeads His-Tag Isolation and Dynabeads Protein G kits (Invitrogen) were used for immunoprecipitation of tau in AD brain homogenate $(250 \mu \mathrm{g})$ with scFv235 or antibody $(10 \mu \mathrm{g})$ using the protocol as per the kit instructions. The pulled-down proteins were separated on $10 \%$ acrylamide gels, followed by Western blotting. The proteins were transferred from the gels onto nitrocellulose membranes. The membrane was blocked with 5\% skimmed milk in PBS for $1 \mathrm{~h}$ at room temperature, and then the blot was incubated with 1:1000 dilution of CP27 (human-specific tau antibody) or total tau antibody (1:5000 dilution; Dako) overnight at $4^{\circ} \mathrm{C}$. This was followed by $2 \mathrm{~h}$ incubation with HRP-conjugated secondary antibody (1:1000) in PBS containing $5 \%$ skim milk. After washing, the proteins on the membrane were detected by enhanced chemiluminescence (Pierce). Images of immunoreactive bands were acquired by Fuji LAS-4000 imaging system.

Human brain tissue staining. The His-tag purified scFv235 was labeled using the Alexa Fluor 568 protein labeling kit (Invitrogen) as per the kit 
a

b

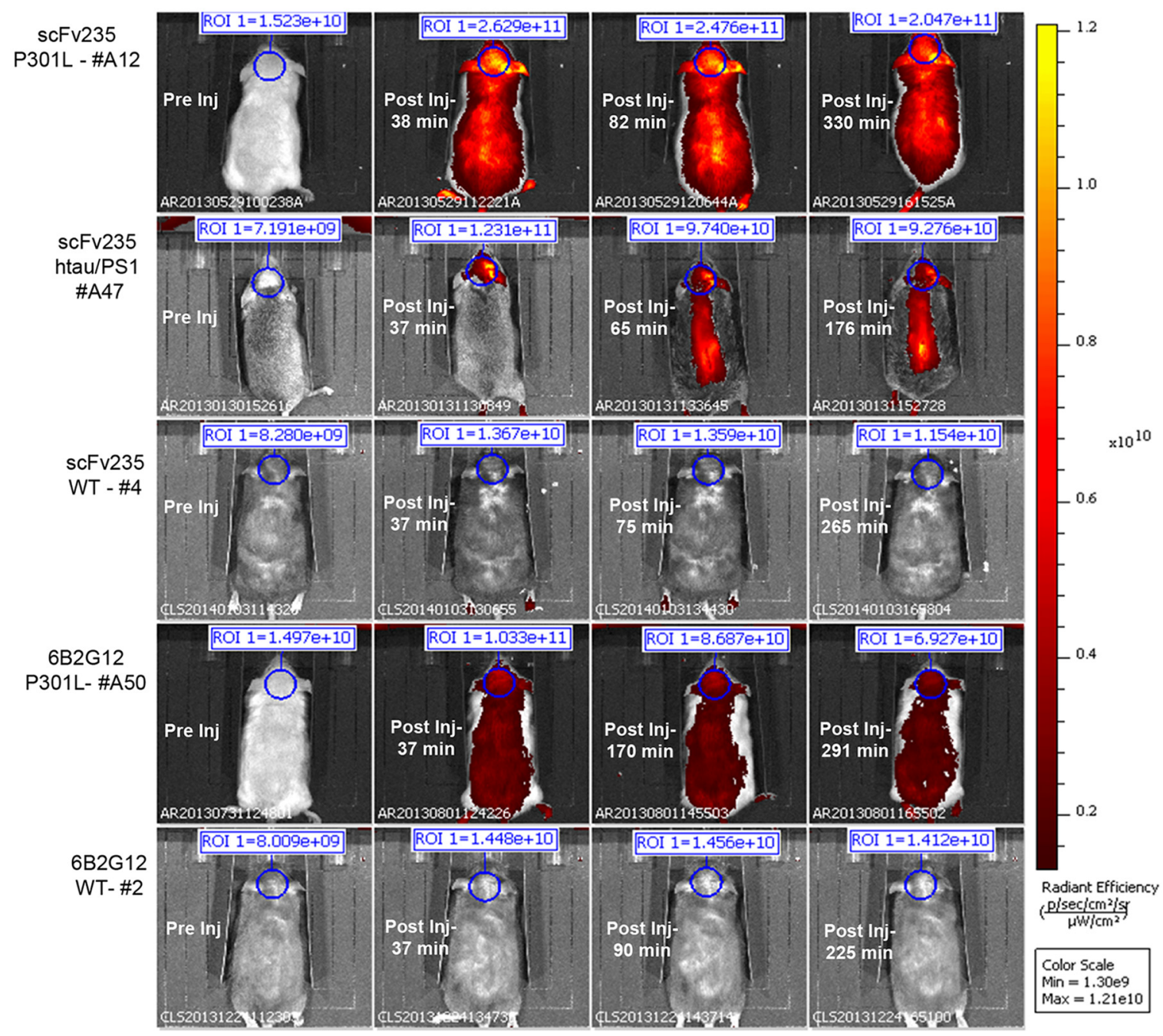

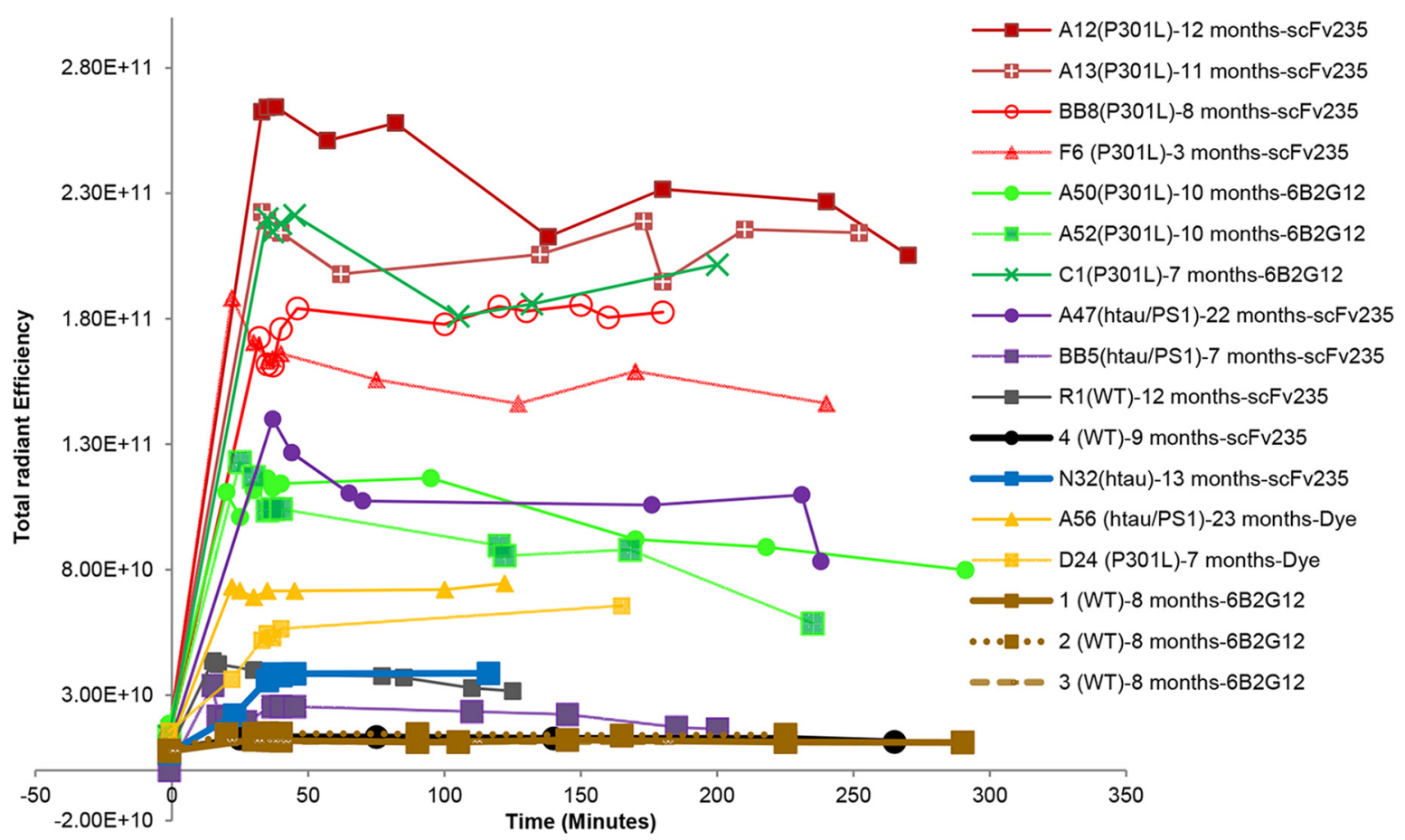

Figure 3. In vivo imaging of tau inclusions in P301L and htau/PS1 mice after intracarotid injection of fluorescently labeled scFv235 or 6B2G12. $\boldsymbol{a}$, Representative mouse images of IVIS brain signal. First row shows images of P301L (12 months old) tg mouse, injected with scFv235 tagged with near infrared dye $(680 \mathrm{~nm})$. The images were recorded before (Figure legend continues.) 
instructions. Several AD, Pick's disease, and age-matched control brains (National Disease Research Interchange) were stained with the 568labeled scFv235 using standard procedures. Briefly, slide-mounted paraffin-embedded brain sections were deparaffinized in xylene and cleared through an ethanol gradient, washed in PBS, followed with epitope unmasking in $0.3 \%$ formic acid and, after PBS washes, were incubated with a mixture of $10 \mu \mathrm{g} / \mathrm{ml} \mathrm{scFv} 235$ and 1:1000 dilution of PHF1 tau antibody culture supernatant overnight at $4^{\circ} \mathrm{C}$. Bound PHF1 was detected with a fluorescently tagged secondary antibody (Alexa Fluor 488 goat anti-mouse IgG, 1:500 dilution; Life Technologies). Nuclei were detected with DAPI and the slides coverslipped with ProLong Gold antifade reagent mounting media (Life Technologies). Images were captured on a Fluoview 1000 laser scanning confocal microscope (Olympus) using wavelength and filters according to the characteristics of the fluorophores.

Animals, injections of labeled antibodies, and IVIS imaging. Mice were housed in Association for Assessment and Accreditation of Laboratory Animal Care-approved facilities and received food and water ad libitum. The experiments were performed under an institutional animal care and use committee-approved protocol. Three different transgenic tangle models were used: htau (1 male; Andorfer et al., 2003), htau/PS1 (4 males; Boutajangout et al., 2010, and JNPL3 (15 males, 1 female; Lewis et al., 2000). Controls were wild-type (WT) mice (4 males, 3 females) and transgenic A $\beta$ plaque mice (Tg-SwDI, 2 males; Davis et al., 2004).

Intracarotid injections were performed as described previously (Asuni et al., 2007). Briefly, mice were anesthetized with $2 \%$ isoflurane and maintained with $1.5 \%$ isoflurane in $30 \% \mathrm{O}_{2}$. After exposing the carotid sheath, left common carotid artery (CCA), external carotid artery (ECA), and internal carotid artery (ICA) were exposed via a midline incision. A silk suture was tied to the distal end of the ECA and the left CCA, ICA, and pterygopalatine artery were temporarily tied. A 30 gauge needle connected to PE-10 tubing (Becton Dickinson) was attached to a $1 \mathrm{ml}$ syringe and $250 \mu \mathrm{g}$ of labeled scFv235 in $500 \mu \mathrm{l}$ PBS was then administered into the common carotid artery over a period of 10-15 min. Krazy Glue was applied to the site of injection to prevent postoperative bleeding.

Alternatively, mice were injected into the femoral vein using the same dose. The medial side of the right thigh was shaved and cleaned with Betadine solution and $70 \%$ ethanol. A small incision $(0.5 \mathrm{~cm})$ parallel to the vein was made on the skin of the internal side of the thigh. When the buttonhole of skin opens, the femoral vein is visible. A 30 gauge needle connected to PE-10 tubing was attached to a $1 \mathrm{ml}$ syringe and adminis-

\footnotetext{
(Figure legend continued.) injection and after injection at 38, 82, and 330 min. Signal was detected throughout the body with highest intensity (yellow) in the brain that slowly decreased over time. Second row contains images from an scFv235-injected htau/PS1 tg mouse (22 months) recorded before and after injection at 37, 65, and $176 \mathrm{~min}$. Again, the most intense signal was detected in the brain and gradually decreased over time. The htau/PS1 model had less signal than P301L mice both in brain and periphery. Third row depicts scFv235 injected WT mouse ( 9 months) before and after injection at 37, 75, and 265 min. Very limited brain signal was detected after injection with no signal in periphery. Fourth row shows images of 6B2G12injected P301L tg mouse (10 months) recorded before and after injection at 37, 170, and 291 min. Signal was strongest in the brain and gradually decreased over time, Fifth row depicts images of 6B2G12-injected WT mouse (8 months) recorded before and after injection at 37, 90, and $225 \mathrm{~min}$. Virtually no signal was detected. The scale bar shows maximum pixel intensity, whereas the ROI is TRE of summed pixel intensity. $\boldsymbol{b}$, Quantitative analysis of IVIS brain signal over time. Highest signal was detected in P301L mice injected with scFv235. The older mice (11 and 12 months) had substantially stronger peak signal than the younger mice ( 3 and 8 months) The same P301L model (7-10 months) had strong but lesser brain signal after 6B2G12 injection. Similar signal intensity was observed in a 22-month-old scFv235-injected htau/PS1 mouse, but limited in a 7-month-old htau/PS1 mouse, which was confirmed to lack tau pathology. WT mice (12-13 months) and one htau mouse (13 months) had low signal at all time points and had no tau pathology. Injection of the fluorescent tag alone in an old htau/PS1 mouse (23 months) and a P301L mouse (7 months) gave a higher brain signal than in WT mice injected with scFv235 or antibody, but it was substantially less than in any of the tauopathy mice injected with scFv235 or 6B2G12. These two dye-injected mice were confirmed to have extensive tau pathology (Table 2). scFv235: $n=4$ P301L, 2 htau/PS1, 1 htau, and 2 WT mice. 6B2G12: $n=3$ P301L, and 3 WT mice. Fluorescent tag (dye): $n=1$ P301L and 1 htau/PS1 mice.
}

tered through the needle punctured upward into the femoral vein over a period of 3-5 min manually. Once the needle was removed, the site of the puncture was compressed with a cotton-tipped applicator to avoid bleeding. As soon as the blood flow had ceased, the skin was sutured with $4 / 0$ braided silk thread using single interrupted sutures. For in vivo imaging system (IVIS) imaging, scFv235, 6B2G12, or pooled mouse IgG was conjugated with VivoTag 680XL (PerkinElmer). The mice were shaved on the head and body to avoid light diffraction caused by the fur. After intracarotid or intravenous injection, mice were subjected to imaging at defined intervals as detailed in Figures 3 and 4 in IVIS Lumina XR (PerkinElmer). The animals were positioned inside the imaging chamber and kept anesthetized with $2 \%$ isoflurane delivered with $\mathrm{O}_{2}$ via a nosecone at a flow rate of $\sim 0.6 \mathrm{~L} / \mathrm{min}$. The mice were kept at $37^{\circ} \mathrm{C}$ body temperature via the thermoelectrically controlled imaging stage. Using Living Image software (PerkinElmer), fluorescent images were obtained with the following settings: mode $=$ fluorescent, illumination $=$ epiillumination, exposure time and binning $=$ auto $(\sim 30 \mathrm{~s}$ under these conditions $)$, excitation filter $=675 \mathrm{~nm}$, emission filter $=$ Cy5.5 $(695-770$ $\mathrm{nm}$ ). All of the acquired image data were automatically time and date stamped to facilitate analysis.

Analysis of IVIS images. Images were analyzed using Living Image software from PerkinElmer. First, individual mouse images from different time points of the longitudinal study were loaded together as a sequence. Next, all images in the sequence were set to the same color scale for easy visual comparison and circular region of interest (ROI) was drawn in the brain region of each animal. Finally, the calibrated unit of radiant efficiency (photos $/ \mathrm{s} / \mathrm{cm}^{2} / \mathrm{Str} / \mathrm{mW} / \mathrm{cm}^{2}$ ) was reported for each ROI and a separate table with all ROI values in the sequence was created and saved.

Immunohistochemistry of mouse brain sections. After imaging, the brain tissue was processed as described previously (Asuni et al., 2007). Briefly, the mice were perfused trans-aortically with PBS and the brains were removed and fixed in $2 \%$ paraformaldehyde/lysine/periodate overnight, placed in $2 \%$ DMSO in $20 \%$ glycerol phosphate buffer overnight, and then sectioned as serial coronal $40 \mu \mathrm{m}$ sections to detect 680XL-scFv235 signal and to determine $\mathrm{scFv}$ subcellular location by costaining with markers of tau protein and the endosomal/autophagosomal/lysosomal system. Sectioned series (400 $\mu \mathrm{m}$ apart) were stored in ethylene glycol cryoprotectant at $-30^{\circ} \mathrm{C}$ until used for immunohistochemistry. Immunofluorescence staining was performed per standard protocol on free floating sections. Briefly, after PBS washes, $0.3 \%$ Triton X-100 permeabilization, and block in 5\% BSA, tissue was incubated with antibodies (1:500-1:1000) overnight at $4^{\circ} \mathrm{C}$ [tau (Tau5, MC1, PHF1), microglia (Iba1), early endosomes (EEA1), late endosomes/lysosomes (rab7), and autophagosomes (LC3 and P62). Bound antibodies were detected with an Alexa Fluor 488 goat anti-mouse/rabbit IgG (Invitrogen) and nuclei with DAPI. After coverslipping with ProLong Gold, the tissue was analyzed with an LSM 700 Zeiss confocal laser scanning microscope.

Confocal imaging analysis. The extent of staining with each label and their colocalization was rated using a semiquantitative scale of $0-4$, with 1-4 indicating increasing degree of these parameters (1: minimal; 2 : modest; 3: moderate; 4: extensive). Such analysis was performed for the following: (1) residual signal of the injected fluorescently tagged scFv/ antibody; (2) degree of brain tau pathology; (3-4) extent of colocalization of injected scFv/antibody signal with tau antibody staining (3) or endosome/lysosome/autophagosome antibody staining (4).

Colocalization of the injected probes and various markers was conducted using intensity correlation analysis (Li et al., 2004). For cells with green and red staining, image contrast was set to minimize bleedthrough (range, 100-150), background was subtracted and intensity correlation analysis was conducted using an ImageJ plugin from the Biophotonics Facility at McMasters University. Images depicting product of difference from the mean (PDM) are shown in individual figures, with yellow in these and merged images indicating colocalization. Blue/white signal in PDM images indicate negative intensity correlation (lack of colocalization).

Statistics. Correlation analysis between the different parameters described in Figure 11 was analyzed by Spearman rank correlation (Prism 6.0; GraphPad). When scFv235 or 6B2G12 brain tissue signal was one 


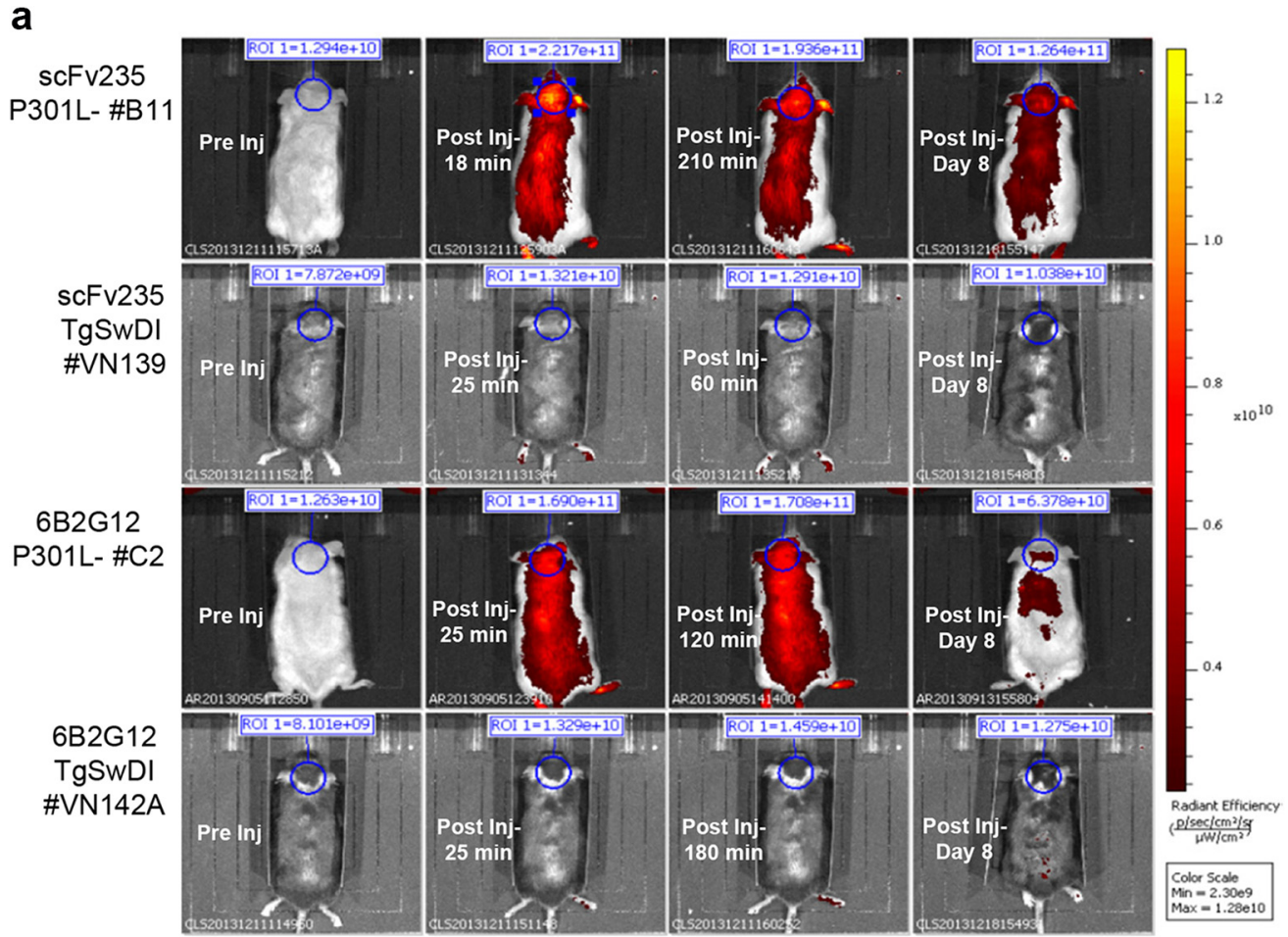

b
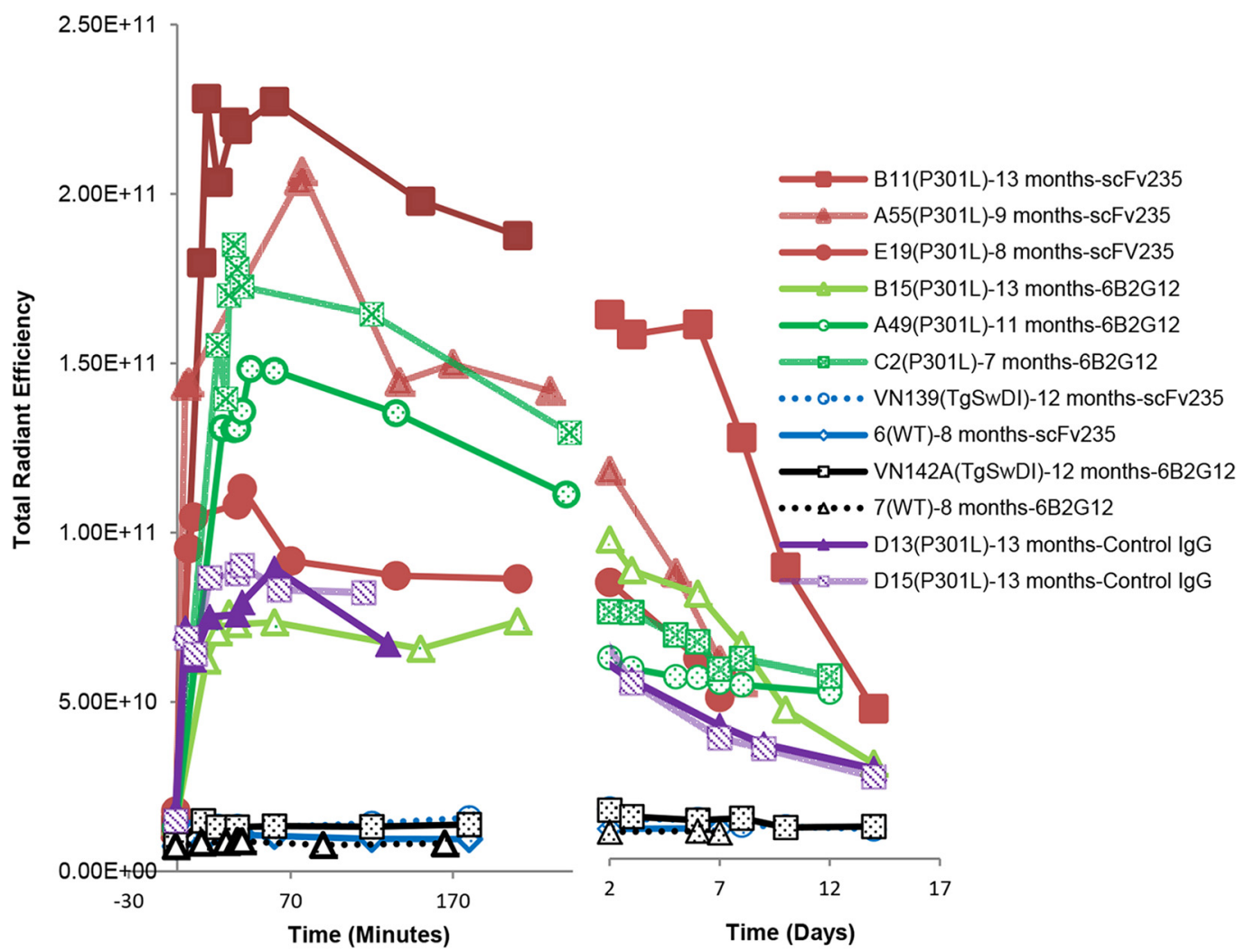

Figure 4. In vivo imaging of tau inclusions in P301L mice after intravenous injection of fluorescently labeled scFv235 or 6B2G12. $a$, Representative mouse images of IVIS brain signal. First row shows images of scFv235-injected P301L (13 months) tg mouse recorded before and after injection at 18, 210, and 11,520 min (day 8). As with the intracarotid injection (Fig. 3), signal was detected throughout the body with the highest intensity (yellow) in the brain that decreased over time. Second row depicts scFv235 injected Tg-SwDI A $\beta$ plaque mouse ( 12 months) before and after injection at 25, 60, and $11520 \mathrm{~min}$. Very limited brain signal was detected after injection with no signal in periphery. Third row includes images of 6B2G12-injected P301L tg mouse (7 months) taken before and after injection at 25, 120, and $11520 \mathrm{~min}$ (day 8). As with the intracarotid injection (Fig. 3), signal was strongest in the brain and gradually decreased over time. Fourth row is of 6B2G12 injected Tg-SwDI mouse (12 months) before and after injection at 25, 180, and $11520 \mathrm{~min}$ (day 8). Very limited brain signal was detected after injection with no signal in periphery. $\boldsymbol{b}$, Quantitative analysis of IVIS brain signal over time. scFv235, 6B2G12, or control pooled lgG were injected into P301L mice. These mice could be imaged at earlier time points after injection than (Figure legend continues.) 
parameter, only mouse brains removed within few hours after injection were included because the brain tissue signal weakens over time. All of the mice listed in Figure $3 b$ were analyzed except N32 because it was killed $7 \mathrm{~d}$ after imaging and the control dye-injected mice (A56 and D24). For correlations between IVIS signal and tau pathology, all of the scFv235 or 6B2G12 injected mice were included (see Figs. $3 b$ and $4 b$ for lists of mice). In addition, one mouse, B32, was not included in IVIS signal correlations as IVIS images could not be obtained because of temporary instrument malfunction (for the number of mice per each correlation, see Figure 11; numbers next to graph point indicate when one point represents two or more overlapping animals; also see Table 2, which shows all of the animals that were analyzed).

\section{Results \\ scFv generation}

pComb3XSS phagemid vector was used to clone the variable regions of the 6B2G12 tau antibody hybridoma, which we have described previously (Congdon et al., 2013; Gu et al., 2013), to construct an scFv library. scFv's were subsequently generated from the library using phage display and panning technique. Based on their affinity and phosphoselective binding to the serine 396, 404 epitope of the tau protein, a few scFv's of thousands were selected for purification and further characterization. A single construct, scFv235, was chosen for in vivo imaging based on its phospho-epitope selectivity both when the peptide is coated on ELISA plates as well as in Biacore when the fragment is immobilized and the binding peptides are in solution (Fig. 1a,b). Additional characterization showed that $\mathrm{scFv} 235$ or its parent antibody, 6B2G12, coprecipitated with tau protein in brain homogenate of Alzheimer's brain. scFv235 detected only full-length tau protein bands (Fig. 1c), whereas 6B2G12 bound to both fulllength and degraded tau fragments (Fig. 1d). Furthermore, scFv235 or 6 B2G12 showed partial colocalization staining with pathological PHF1-positive tau on fixed Alzheimer's and Pick's disease brain tissue (Fig. 2; for 6B2G12 staining, see (Gu et al., 2013). Importantly, limited staining was detected in control human brain. Overall, these findings suggested their potential as imaging agents.

\section{Imaging studies}

Subsequent imaging studies using IVIS revealed strong brain signals from transgenic $(\mathrm{tg})$ tauopathy mice when near-infrareddye-labeled-scFv235 was injected into the right carotid artery $(250 \mu \mathrm{g} / 500 \mu \mathrm{l})$. The signal remained high and relatively stable for at least 250-300 min (Fig. 3a,b). JNPL3 mice (Lewis et al., 2000 ), with the P301L tau mutation showed stronger signal than htau/PS1 mice (Boutajangout et al., 2010), which have milder overall tau pathology. Brain signal from scFv235-injected P301L mice peaked at $35-38 \mathrm{~min}$ (1714\% above preinjection baseline signal) and remained strong at 82 and $330 \mathrm{~min}$ after injection ( $1675 \%$ and $1468 \%$, respectively). In the htau/PS1 mice, the scFv235 brain signal peaked at $37 \mathrm{~min}$ ( $1443 \%$ above preinjection

\footnotetext{
$\leftarrow$

(Figure legend continued.) the intracarotid-injected mice because the latter route requires longer postoperative care to prevent bleeding. Peak signal was generally obtained within the first hour after injection, depending on the animal, at similar intervals for all probes. Overall signal was substantially higher for scFv235 and 6B2G12 compared with control lgG, even though the IgG-injected mice had the most robust tau pathology (Table 2). One 6B2G12-injected mouse (B15) had comparable IVIS signal to the lgG-injected mice but more modest tau pathology. The signal gradually subsided over $14 \mathrm{~d}$ at different rates for individual P301L mice. Very limited signal was detected at all time points in injected Tg-SwDI or WT mice with either probe. scFv235: $n=3$ P301L, 1 Tg-SwDI, and 1 WT mice. 6B2G12: $n=3$ P301L, 1 Tg-SwDI and 1 WT mice. Control lgG: $n=2$ P301L mice.
}

baseline signal) and remained strong at 65 and $176 \mathrm{~min}$ after injection (1144\% and 1093\%, respectively). The htau/PS1 model had less signal than P301L mice both in brain and periphery. Older mice within each genotype had stronger signal than younger mice, which is as expected because these should have more advanced tau pathology. Minimal signal was observed in WT mice injected with the same probe or in tangle mice that received only the fluorescent dye alone without the scFv. The antibody from which the $\mathrm{scFv}$ was derived, $6 \mathrm{~B} 2 \mathrm{G} 12$, provided similar results when injected at the same dose and via the same route, albeit its signal intensity was substantially less. Imaging at $20-95$ min after injection showed a signal of $600-632 \%$ above baseline value, with a modest reduction at the depicted 170 and $291 \mathrm{~min}$ (497\% and 431\%, respectively).

Older (11-12 months) P301L mice injected with scFv235 had peak brain signal [total radiant efficiency (TRE)] of $2.23 \mathrm{E}+11$ and $2.64 \mathrm{E}+11$ respectively, whereas the younger mice ( 3 and 8 months) had lower peak signals of $1.88 \mathrm{E}+11$ and $1.86 \mathrm{E}+11$, respectively. The same P301L model (7-10 months) had strong but lesser brain signal after 6B2G12 injection, ranging from $2.20 \mathrm{E}+11$ to $1.16 \mathrm{E}+11$. Similar signal intensity was observed in an old scFv235-injected htau/PS1 mouse (22 months; peak at $1.40 \mathrm{E}+11$ ) but limited in a 7-month-old htau/PS1 mouse, which was confirmed to lack tau pathology. WT mice (12-13 months) and one htau mouse (13 months) had low signal at all time points and had no tau pathology. Injection of the fluorescent-tag alone in an old htau/PS1 mouse (23 months) and a P301L mouse (7 months) gave a higher brain signal than in WT mice injected with scFv235 or 6 B2G12, but it was substantially less than in any of the tauopathy mice injected with the scFv or antibody. These two dye-injected mice were confirmed to have extensive tau pathology (see Table 2). Brains were subsequently removed for further analyses to verify the presence and subcellular location of scFv235 or 6B2G12 or lack thereof in the Tg tauopathy or WT brains (see Figs. 5, 6, 7, 8, 9, and 10). Both tau probes were detected primarily in neurons, partially colocalized with pathological tau proteins and exclusively in the endosome-autophagosome-lysosome (E-A-L) system (Figs. 5, 6, 8). A smaller portion was detected in microglia (Fig. 6). No probe signal was detected in WT mice (Figs. 7, 9). Tg mice with weak IVIS brain signal after the diagnostic ligand injection had limited tau pathology (see summary in Tables 1 and 2).

Following these promising findings after intracarotid injection, we assessed the feasibility of using the intravenous route, which would be more useful for multiple injections and for clinical use. Strong brain signals were also observed for both ligands when this route of administration was used. Longer imaging sessions were conducted in the intravenously injected mice, showing a gradual clearance of the signal over 8-14 d (Fig. $4 a, b$ ). As for the intracarotid injection, mice injected with the scFv showed generally stronger signal than mice injected with the tau antibody. In intravenously injected P301L mice, peak scFv235 brain signal was detected at $18 \mathrm{~min}$ (1754\% above preinjection baseline), with lesser signal at $210 \mathrm{~min}$ (18\% reduction from peak signal), which substantially subsided at $8 \mathrm{~d}$ (43\% reduction). In 6B2G12antibody-injected mice, brain signal was strong at $25 \mathrm{~min}(1211 \%$ above preinjection baseline), peaked at $35 \mathrm{~min}$ (1445\%), with lesser signal at $120 \mathrm{~min}$ (11\% reduction from peak signal), and was much weaker by 8 and $12 \mathrm{~d}(67 \%$ and $70 \%$ reduction, respectively). P301L mice injected with control pooled IgG had modest IVIS signal despite having very extensive tau pathology and the brain signal did not colocalize with tau markers (Table 2, Fig. 10). Such lack of colocalization is analogous to our prior tissue 

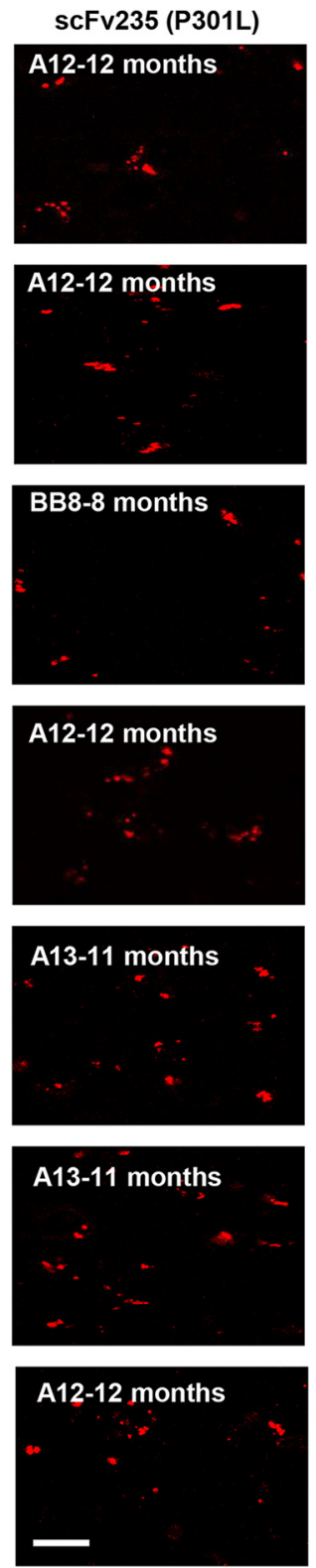
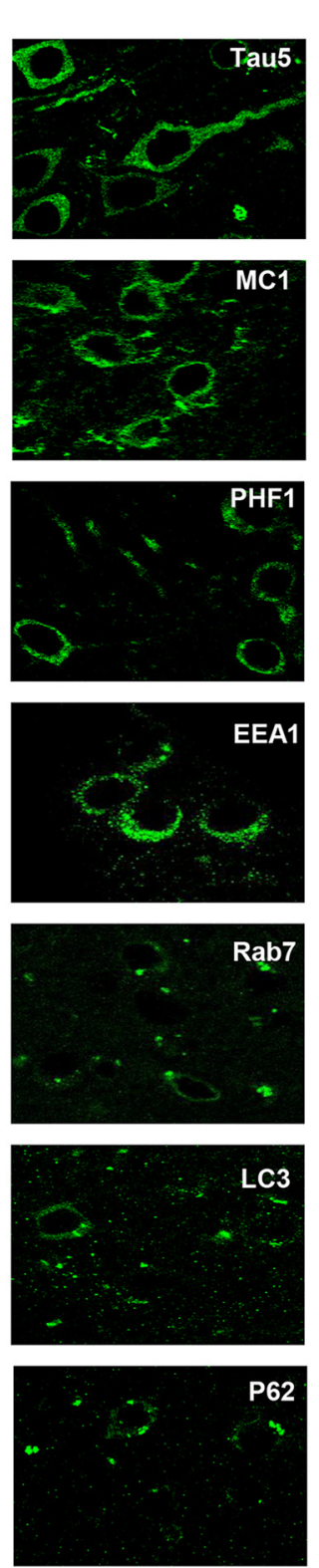
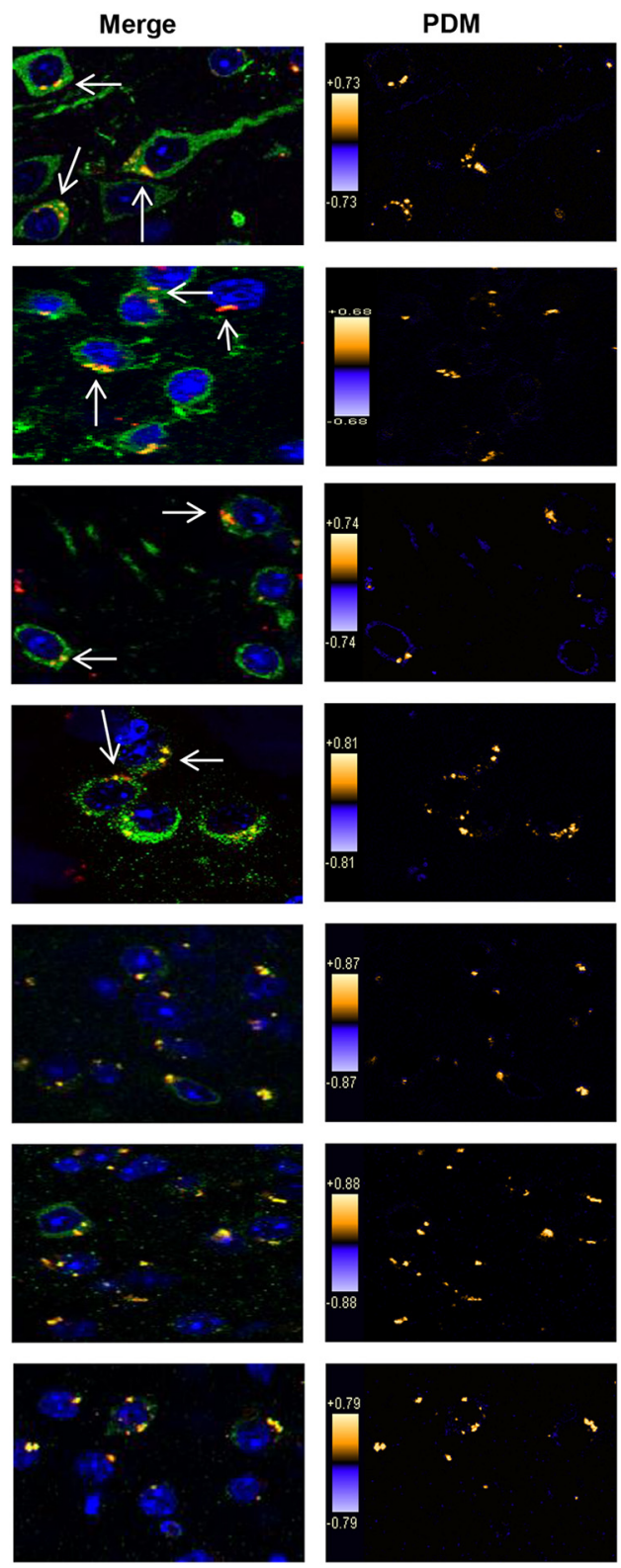

Figure 5. Colocalization of injected scFv235 with intraneuronal tau aggregates and markers of E-A-Lin P301L mice. Brains were removed 3- 4 h after intracarotid injection of fluorescently tagged scFV235 and IVIS imaging, fixed, sectioned coronally, and stained for the following: (1) tau with Tau5 (total tau), MC1 (conformational), PHF1 (phospho-tau), (2) early endosomes (EEA1), (3) late endosomes/lysosomes (Rab 7); and (4) autophagosomes (LC3, P62) and microglia (Iba-1). scFv235-injected P301L mice showed partial colocalization with MC1, Tau5, and PHF1 and complete colocalization with Rab7, EEA1, LC3, and P62. Nuclei are stained blue with Hoechst nuclear stain and are shown in merged images. Scale bar, $10 \mu \mathrm{m}$. Arrows point at some of the neurons with partial colocalization. No arrows were used when there was complete colocalization. Yellow in merged and PDM images indicates colocalization.

findings in P301L mice $1 \mathrm{~h}$ after intracarotid injection of control IgG (Asuni et al., 2007). WT or mice with A $\beta$ plaques (TgSwDI; Davis et al., 2004) had minimal IVIS brain signal at all time points, highlighting the specificity of the probes for tau pathology. As with the intracarotid injection, the scFv or tau antibody colocalized with pathological tau and the probes were detected in the E-A-L system within neurons and to some extent in microglia (data not shown; see summary in Tables 1 and 2).

Comparison of the degree of the IVIS signal, residual scFv, or antibody signal from sectioned brains and the extent of tau pathology after both routes of administration revealed excellent correlation between these parameters (Fig. 11, scFv235: IVIS signal vs brain tissue $\mathrm{scFv}$ signal, $r=0.94, p=0.0018$; IVIS signal vs brain tau pathology, $r=0.86, p=0.0001$; brain tissue scFv signal vs brain tau pathology, $r=0.81, p=0.0048 ; 6 B 2$ G12: IVIS signal vs brain tissue $6 \mathrm{~B} 2 \mathrm{G} 12$ signal, $r=0.87, p=0.1$; IVIS signal vs brain tau pathology, $r=0.90, p=0.0004$; brain tissue $6 \mathrm{~B} 2 \mathrm{G} 12$ signal vs brain tau pathology, $r=0.80, p=0.05$ ). These findings suggest that this particular scFv, its parent antibody and the overall approach works very well to detect and assess the degree of tau pathology in live animals.

\section{Discussion}

Our lead phosphoselective scFv consistently showed strong brain signal after peripheral injection in two tauopathy tangle mouse models, but not in WT or $\mathrm{A} \beta$ plaque mice. Administration of the parent antibody led to similar results at a lesser signal intensity. This is a promising approach for diagnosis and for monitoring treatment efficacy in humans and related tauopathy mouse models that is likely applicable to various protein conformational 
scFv235 (htau/PS1)
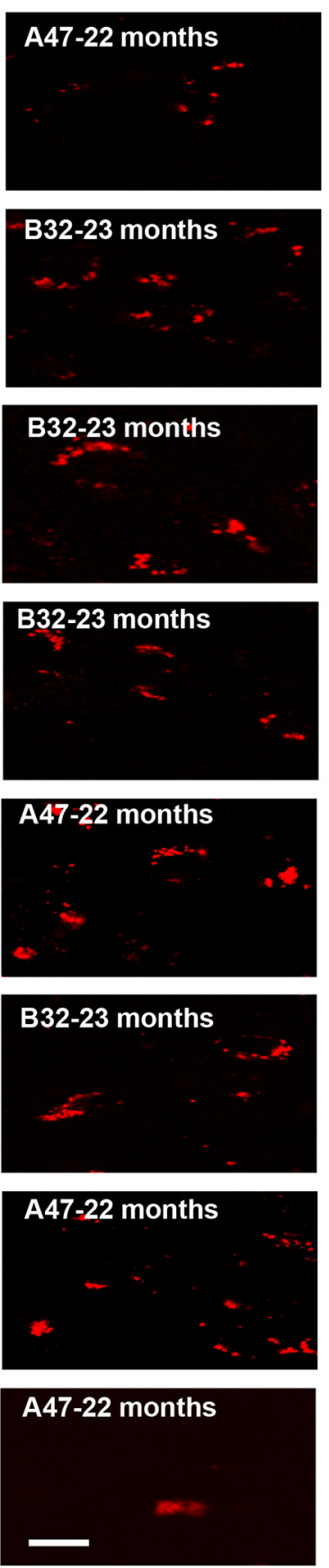

Merge
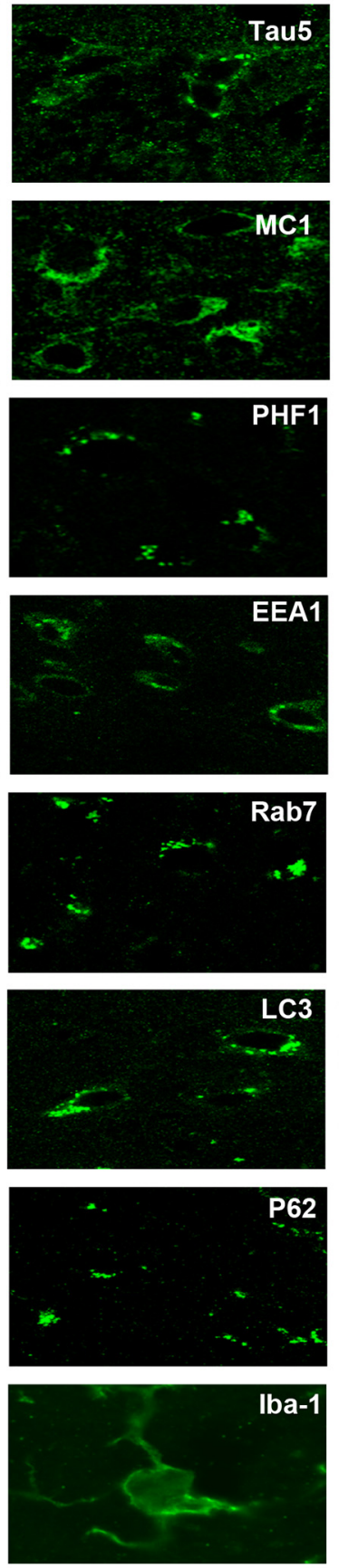
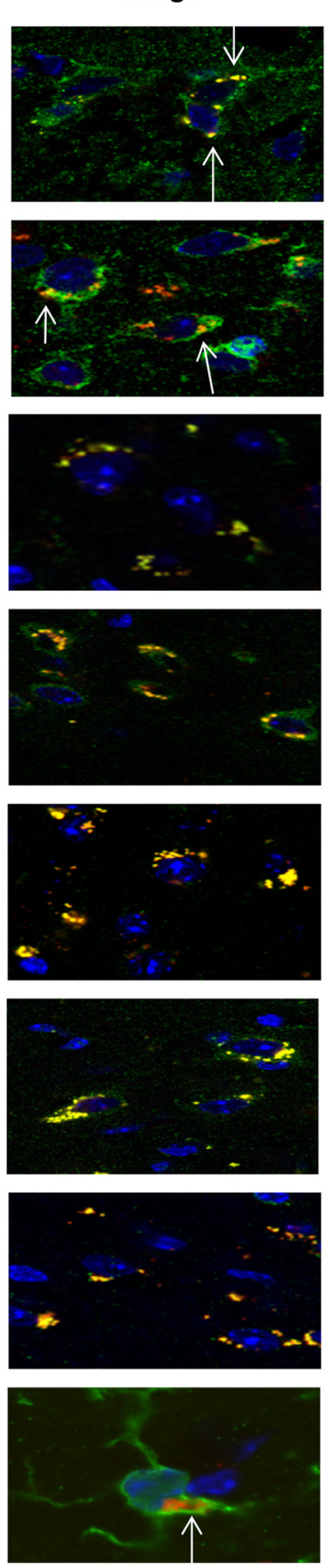

PDM
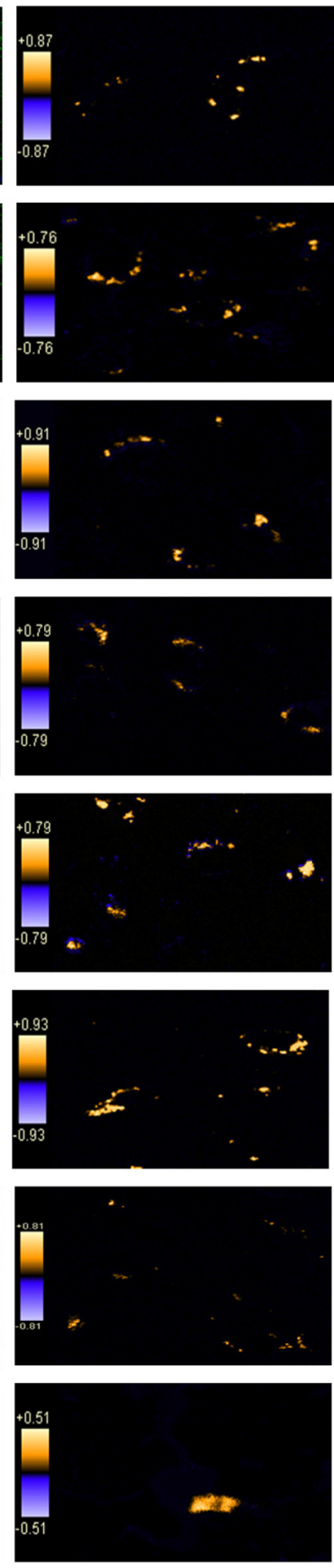

Figure 6. Colocalization of injected scFv235 with intraneuronal tau aggregates, markers of E-A-L, and microglia in htau/PS1 mice. Brains were removed, processed and stained as described in Figure 5 and for microglia (Iba-1). scFv235-injected htau/PS1 mice showed partial colocalization of the injected scFv235 with MC1, Tau5, and Iba-1 and complete colocalization with PHF1, Rab7, EEA1, LC3, and P62 antibodies. Nuclei are stained blue with Hoechst nuclear stain and are shown in merged images. Scale bar, $10 \mu \mathrm{m}$. Arrows point at some of the neurons with partial colocalization. No arrows were used when there was complete colocalization. Yellow in merged and PDM images indicates colocalization.

disorders. The hope for tau-based ligands is that they will be better than $\mathrm{A} \beta$ ligands to monitor the status and progression of neurodegeneration, because tau lesions correlate much better with cognitive deficits than $\mathrm{A} \beta$ pathology (Nelson et al., 2012).

Three different transgenic tauopathy mouse models were used for imaging, as well as WT and A $\beta$ plaque mice as controls. Sample size of each model was low except for JNPL3 mice and not powered sufficiently to determine interanimal variability. However, the excellent correlation among the IVIS signal, residual probe signal in the brain tissue, and the tau pathology bodes well for using this approach for diagnosis of tauopathy in humans and for monitoring treatment efficacy in such patients and related animal models.

The $\mathrm{scFv}$ or its parent antibody were detected primarily in neurons, colocalized with pathological tau proteins in the E-A-L system. Better colocalization of the imaging probes was seen with the PHF1 antibody, which targets the same region, than with $\mathrm{MC1}$ and Tau5, which are directed against a conformational 
scFv235 (Wild type)
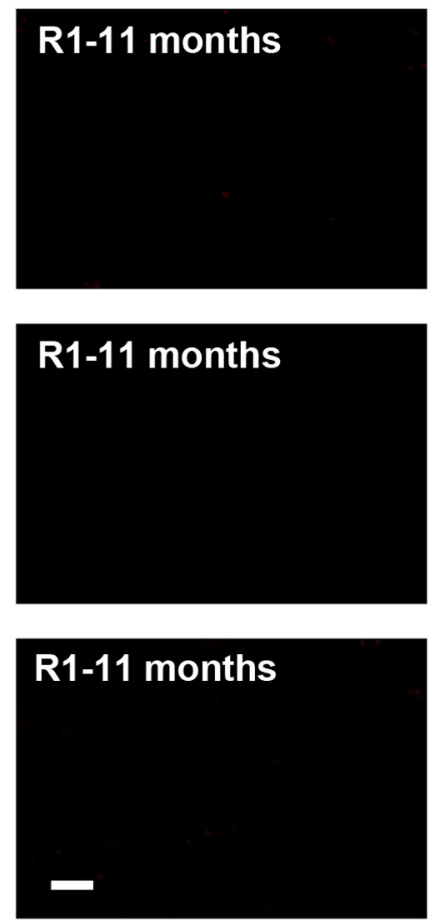
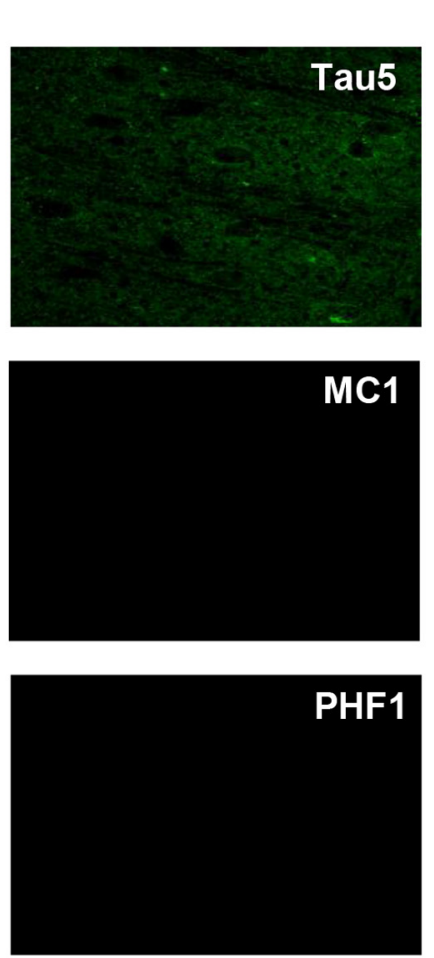

Merge
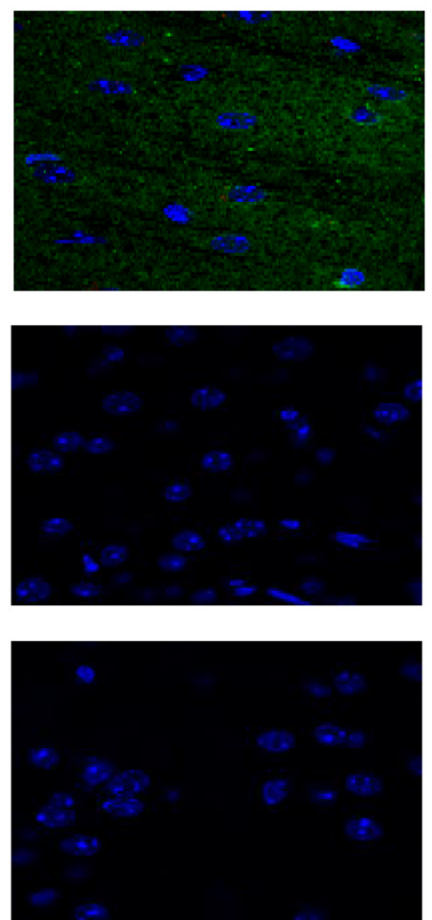

PDM
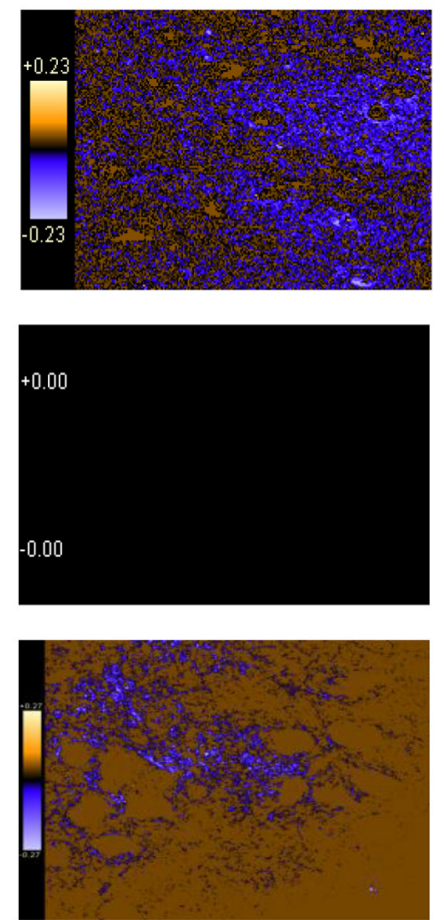

Figure 7. Brain sections from WT mice injected with scFv235 and stained with tau antibodies. WT mice injected with scFv235 showed no signal from the antibody fragment and no staining with the tau antibody markers except for normal tau detected with Tau5. Therefore, no colocalization is seen in merged or PDM images. Nuclei are stained blue with Hoechst nuclear stain and are shown in merged images. Scale bar, $10 \mu \mathrm{m}$.

epitope and total tau protein, respectively. Furthermore, within the E-A-L pathways, the best colocalization of the antibody/scFv was detected with the markers more associated with the lysosomes (Rab7 and P62). With different uptake pathways likely to be involved (Congdon et al., 2014), all of which lead to the lysosomes, this would be predicted. We have observed similar distribution in tauopathy mice of labeled tau antibodies and their Fab fragments after intracarotid injection or administration to brain slice cultures derived from such mice (Asuni et al., 2007; Krishnamurthy et al., 2011; Congdon et al., 2013; Gu et al., 2013). However, this is the first report detecting such aggregates in vivo with antibodies or their fragments as imaging agents. It is evident from prior preclinical and clinical studies targeting $\mathrm{A} \beta$, $\alpha$-synuclein, or the tau protein that antibodies have substantial access into brains with aggregates of these peptides/proteins, presumably because of associated inflammation that leads to opening of the BBB (Lemere and Masliah, 2010; Congdon et al., 2014). We have previously reported that peripherally injected fluorescently tagged antibodies, including control IgG, are easily detected in the brains of JNPL3 tauopathy mice, but not in WT mice, indicating a leaky BBB in the former model. However, because the tau scFv/antibody has a binding partner within the brain, its IVIS signal is much stronger than that of a control IgG even though the mice injected with the latter had more tau pathology (Fig. 4, Table 2). Therefore, tau-pathology-associated leakage of the BBB should not confound the diagnostic use of such tau-imaging ligands.

There are several possible explanations for the lower signal of the antibody compared with the scFv. The antibody is $\sim 6$ times the size of the $\mathrm{scFv}$ ( 150 vs $25 \mathrm{kDa}$ ), which may result in less brain and neuronal uptake. We are injecting the same weight of both $(250 \mu \mathrm{g})$, which contains 6 times fewer molecules of the antibody compared with the fragment. This initial dose was chosen based on our previous study of brain uptake of tagged polyclonal antitau mouse IgG (Asuni et al., 2007). What may counteract these issues is the higher affinity of the antibody for tau compared with the $\mathrm{scFv}$ (Fig. 1). In ongoing IVIS studies, we are working with 5-10 times lower doses and those can likely be much lower in PET studies. The sensitivity of radiolabel PET detection is much greater than of a fluorescent tag with IVIS.

The weak IVIS brain signal in tg mice with limited tau pathology further supports our notion that the enhanced signal in the tg mice is not a mere reflection of tau overexpression, but rather indicates the presence of tau pathology. JNPL3 (P301L) mice exhibit stronger brain and peripheral signal than htau/PS1 mice. Within the brain, this fits with more severe tau pathology. The greater peripheral signal observed in P301L mice compared with the htau/PS1 mice appears in part to be derived from the spinal cord, which is known to have extensive tau lesions in this model (Lewis et al., 2000). In addition, the prion promoter of its mutated tau transgene results in more global tau expression than in the htau/PS1 model. This may potentially lead to tau aggregation in various organs and therefore greater peripheral signal. Because all animals received the same amount of imaging probe, such binding of the probe outside the brain may lead to underestimation of brain tau pathology. However, as evident from the correlation analyses, this is not a confounding variable. With regard to the peripheral signal that appears over time in the htau/PS1 mice, this is likely related to probe clearance.

These imaging probes ( $\mathrm{scFv}$ or antibody) could certainly have therapeutic potential but it is unlikely that a single injection would have a major effect on tau clearance. Reports from us and others show moderate clearance of pathological tau after multiple $(\sim 13)$ weekly injections of different tau antibodies. Similar find- 

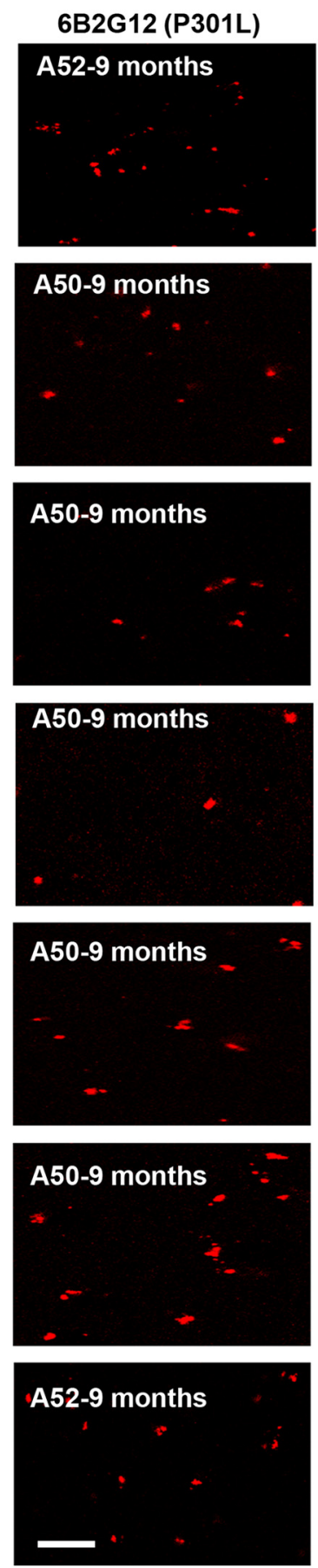
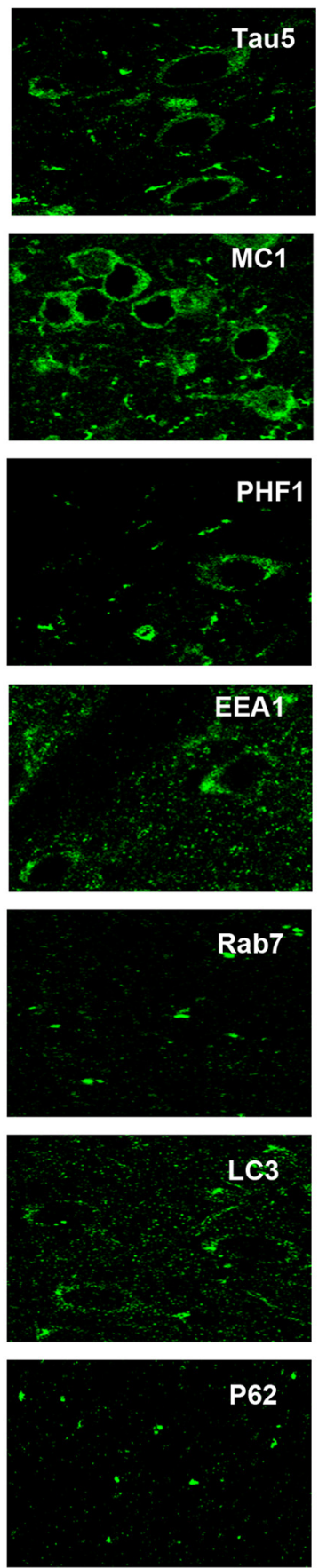
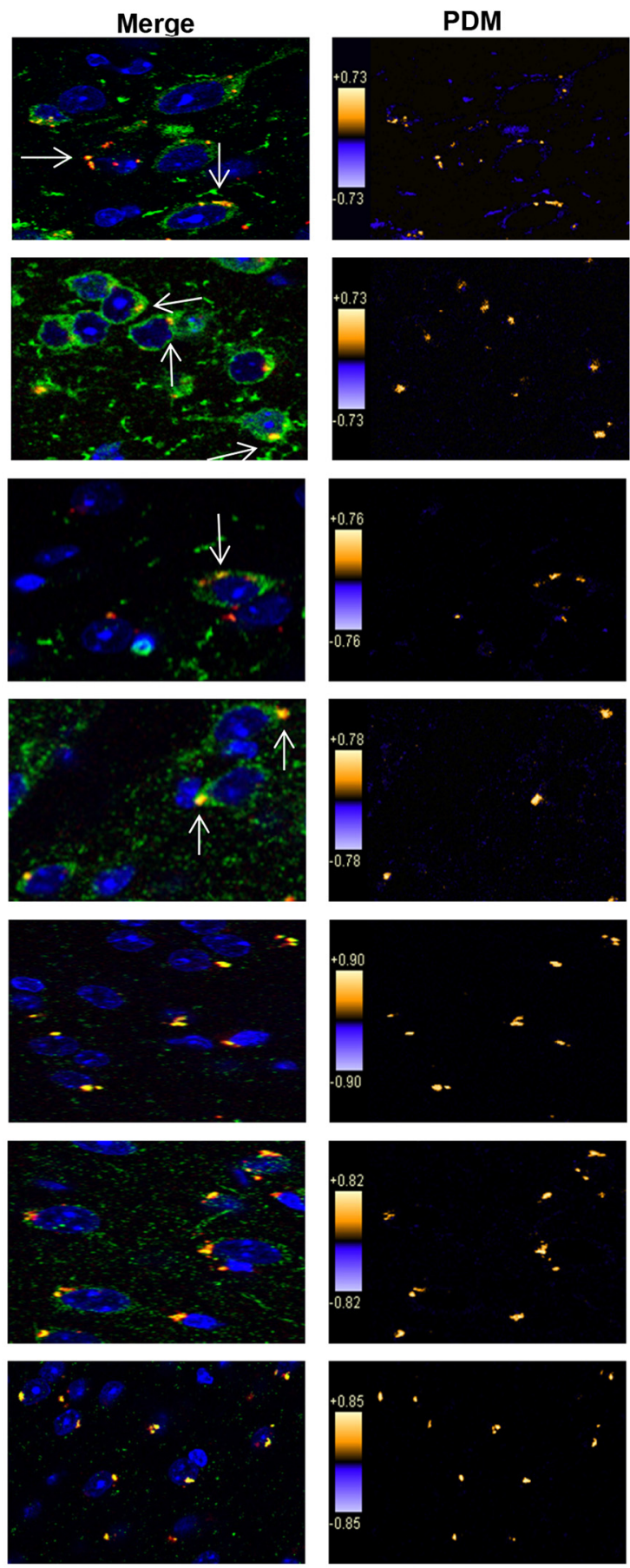

Figure 8. Colocalization of injected $6 \mathrm{~B} 2 \mathrm{G} 12$ with intraneuronal tau protein and markers of E-A-L in P301L mice. Brains were removed 3- $4 \mathrm{~h}$ after intracarotid injection of fluorescently tagged 6B2G12 and IVIS imaging. 6B2G12-injected P301L mice showed partial colocalization with Tau5, MC1, PHF1, and EEA1 and complete colocalization with Rab7, LC3, and P62. Nuclei are stained blue with Hoechst nuclear stain and are shown in merged images. Scale bar, $10 \mu \mathrm{m}$. Arrows point at some of the neurons with partial colocalization. No arrows were used when there was complete colocalization (bottom 3 panels). Yellow in merged and PDM images indicates colocalization.

ings are observed after long-term (several months) active tau immunizations (for review, see Congdon et al., 2014). This view is further supported by our data in the present study showing that IVIS signal correlates very well with the degree of tau pathology and is stable over several hours. However, this may become a confounding variable after multiple imaging sessions and should then be taken into consideration. Because reduction in tau pathology is unlikely to occur under normal circumstances, such potentially diagnostic/therapeutic ligands could then prove their own efficacy by showing correlation of tau clearance with the number of imaging sessions.

For animal studies, IVIS imaging is more cost-effective than positron emission tomography (PET) studies and involves a much simpler probe preparation; that is, its labeling with a near infrared dye instead of a more complicated radiolabeling procedure, which may require an on-site cyclotron. Therefore, IVIS imaging is ideal for probe development to select ligands for subsequent PET studies. Our studies also indicate that it is likely to be 
6B2G12 (Wild type)
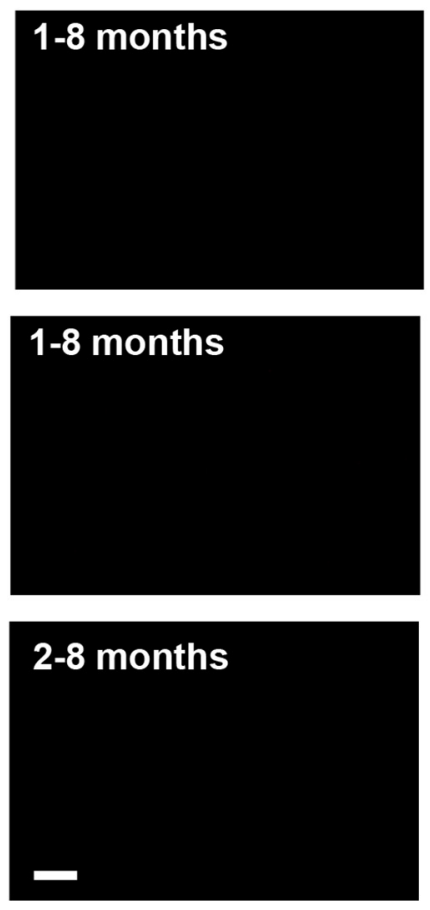
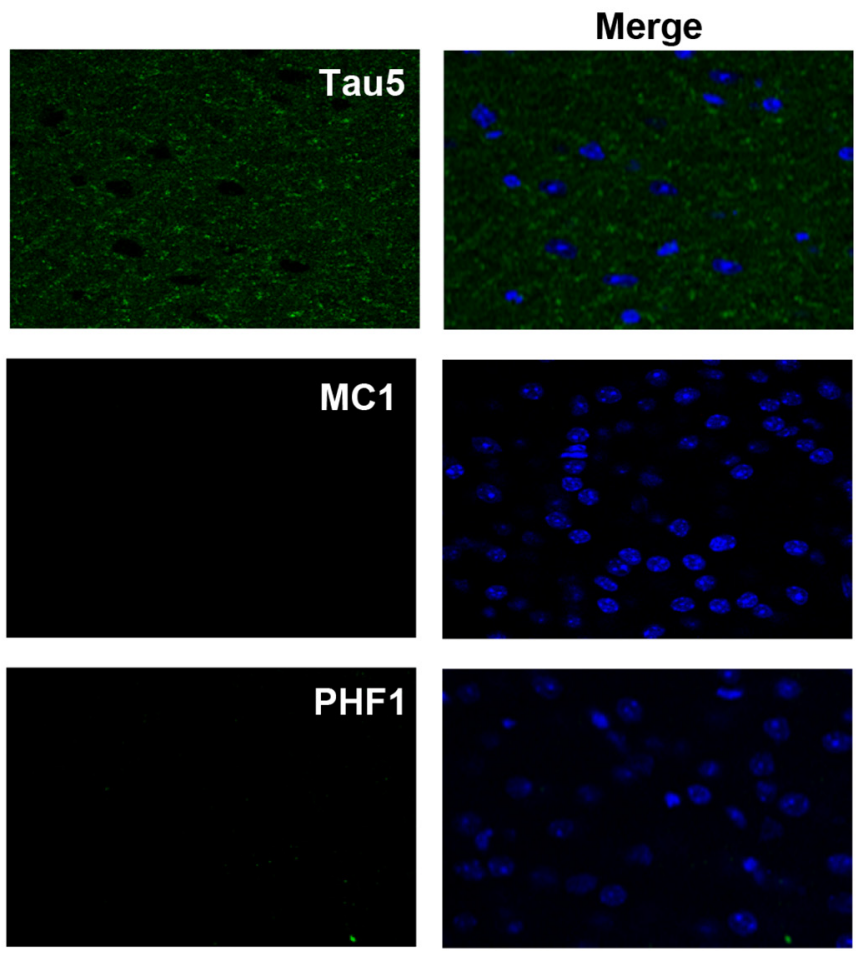
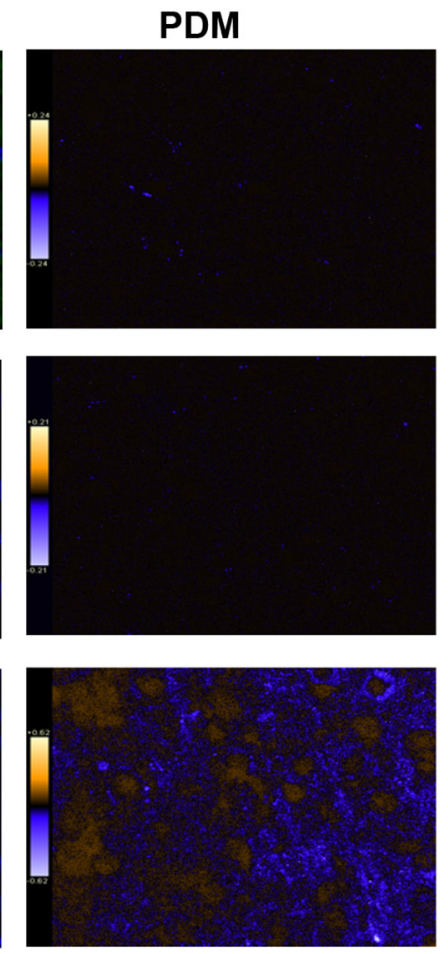

Figure 9. Brain sections from WT mice injected with 6B2G12 and stained with tau antibodies. WT mice injected with $6 \mathrm{~B} 2 \mathrm{G} 12$ showed no signal from the antibody and no staining with the tau antibody markers except for normal tau detected with Tau5. Therefore, no colocalization is seen in merged or PDM images. Nuclei are stained blue with Hoechst nuclear stain and are shown in merged images. Scale bar, $10 \mu \mathrm{m}$.

Table 1. Overview of IVIS imaging studies of mice that received intracarotid or intravenous injection with the diagnostic probes scFv235 or 6B2G12 antibody

\begin{tabular}{|c|c|c|c|c|c|}
\hline Objective & Conjugated dye & Injection route/probe & Mice & Results & \\
\hline \multirow{3}{*}{$\begin{array}{l}\text { Uptake of scFv235 in the } \\
\text { brain and binding to } \\
\text { pathological tau } \\
\text { within neurons }\end{array}$} & \multirow[t]{3}{*}{ Alexa Fluor 568} & Intracarotid/scFv235 & 3 htau/PS1 & Good scFv signal that colocalizes well wi & h Tau5 and MC1 antibody \\
\hline & & \multirow[t]{2}{*}{ Intracarotid/scFv235 } & \multirow[t]{2}{*}{2 WT } & \multicolumn{2}{|l|}{ Limited scFv signal } \\
\hline & & & & IVIS signals & Staining signal \\
\hline \multirow[t]{13}{*}{$\begin{array}{l}\text { Live IVIS imaging for } \\
\text { scFv235/6B2G12 }\end{array}$} & \multirow[t]{13}{*}{ VivoTag 680XL } & \multirow[t]{3}{*}{ Intracarotid/scFv235 } & \multirow[t]{3}{*}{3 htau/PS1 } & Imaging not performed for $\mathrm{B} 32$ mouse & $\begin{array}{l}\text { Strong scFv signal that colocalizes well with tau aggregates } \\
\text { and endosome/autophagosome/lysosome (e/a/L) mark- } \\
\text { ers for B32 mouse }\end{array}$ \\
\hline & & & & Weak signal for $B B 5$ mouse & Weak scFv signal and no tau pathology for BB5 mouse \\
\hline & & & & $\begin{array}{l}\text { Strong signal in the right hemisphere } \\
\text { that slowly decreases up to } 4 \mathrm{~h} \text { for } \\
\text { A47 mouse }\end{array}$ & $\begin{array}{l}\text { Strong scFv signal that colocalizes well with tau aggregates } \\
\text { and e/a/L markers for A47 mouse }\end{array}$ \\
\hline & & Intracarotid/scFv235 & $4 \mathrm{P} 301 \mathrm{~L}$ & $\begin{array}{l}\text { Strong scFv signal that is sustained } \\
\text { even after } 5 \mathrm{~h}\end{array}$ & $\begin{array}{l}\text { Strong scFv signal that colocalizes well with tau aggregates } \\
\text { and e/a/L markers }\end{array}$ \\
\hline & & Intracarotid/scFv235 & $\begin{array}{l}2 \text { WT and } 1 \\
\text { htau }\end{array}$ & Weak signal & Weak scFv signal. Limited (htau) or no (WT) tau pathology \\
\hline & & Intracarotid/free dye & $2 \mathrm{P} 301 \mathrm{~L}$ & Modest signal & Weak signal that does not colocalize with tau aggregates \\
\hline & & Intracarotid/6B2G12 & $3 \mathrm{P} 301 \mathrm{~L}$ & $\begin{array}{l}\text { Strong signal that slowly decreases the } \\
\text { next } 3-5 \mathrm{~h}\end{array}$ & $\begin{array}{l}\text { Strong 6B2G12 signal that colocalizes well with tau aggre- } \\
\text { gates and e/a/L markers }\end{array}$ \\
\hline & & Intracarotid/6B2G12 & 3 WT & Weak signal & Weak 6B2G12 signal; no tau pathology \\
\hline & & Intravenous/scFv235 & $3 \mathrm{P} 301 \mathrm{~L}$ & $\begin{array}{l}\text { Strong signal up to } 1 \mathrm{~h} \text { that slowly } \\
\text { decreases the next } 3 \mathrm{~h}\end{array}$ & $\begin{array}{l}\text { Weak scFv signal after } 7-31 \mathrm{~d} \text { that colocalizes well with tau } \\
\text { aggregates and } / \mathrm{a} / \mathrm{L} \text { markers }\end{array}$ \\
\hline & & Intravenous/scFv235 & $\begin{array}{l}1 \mathrm{TgSw} \text { DI, } \\
1 \text { WT }\end{array}$ & Weak signal & Weak scFv and tau antibody signals \\
\hline & & Intravenous/6B2G12 & $3 \mathrm{P} 301 \mathrm{~L}$ & $\begin{array}{l}\text { Strong signal up to } 1 \mathrm{~h} \text { that slowly } \\
\text { decreases the next } 3 \mathrm{~h}\end{array}$ & $\begin{array}{l}\text { Weak signal after } 7-31 \mathrm{~d} \text { that colocalizes well with tau } \\
\text { aggregates and e/a/L markers }\end{array}$ \\
\hline & & Intravenous/6B2G12 & $\begin{array}{l}1 \mathrm{TgSw} \text { DI, } \\
1 \text { WT }\end{array}$ & Weak signal & Weak 6B2G12 signal; no tau pathology \\
\hline & & Intravenous/control lgG & $2 \mathrm{P} 301 \mathrm{~L}$ & Modest signal & $\begin{array}{l}\text { Weak control IgG signal; extensive tau pathology but lgG } \\
\text { signal does not colocalize with tau aggregates }\end{array}$ \\
\hline
\end{tabular}


Table 2. IVIS signal (maximum total radiant efficiency) and semiquantitative assessment of probe signal from the brain sections, tau pathology, and colocalization of the injected probe with various markers of the tau protein and the endosome-autophagosome-lysosome system

\begin{tabular}{|c|c|c|c|c|c|c|c|c|c|c|c|c|c|c|}
\hline \multirow[b]{2}{*}{ Mice ID } & \multirow[b]{2}{*}{ Strain } & \multirow{2}{*}{$\begin{array}{l}\text { Age } \\
(\mathrm{mo})\end{array}$} & \multirow{2}{*}{$\begin{array}{l}\text { Injected material/ } \\
\text { route intracarotid } \\
\text { (IC)/intravenous (IV) }\end{array}$} & \multirow{2}{*}{$\begin{array}{l}\text { IVIS-maximum } \\
\text { total radiant } \\
\text { efficiency }\end{array}$} & \multirow{2}{*}{$\begin{array}{l}\text { Brain } \\
\text { removal } \\
\text { after } \\
\text { injection }\end{array}$} & \multirow{2}{*}{$\begin{array}{l}\text { Brain } \\
\text { signal in } \\
\text { sections }\end{array}$} & \multirow{2}{*}{$\begin{array}{l}\text { Brain tau } \\
\text { pathology }\end{array}$} & \multicolumn{3}{|c|}{ Colocalization with tau markers } & \multicolumn{4}{|c|}{$\begin{array}{l}\text { Colocalization with endosome/ } \\
\text { lysosome/autophagy markers }\end{array}$} \\
\hline & & & & & & & & Tau5 & MC1 & PHF1 & EEA1 & Rab7 & LC3 & P62 \\
\hline BB8 & P301L & 8 & IC-scFv235 & $1.86 \mathrm{E}+11$ & $180 \mathrm{~min}$ & +++ & +++ & +++ & +++ & +++ & +++ & +++ & +++ & +++ \\
\hline $\mathrm{A} 12$ & P301L & 12 & IC-scFv235 & $2.64 \mathrm{E}+11$ & $330 \mathrm{~min}$ & ++++ & ++++ & +++ & +++ & +++ & +++ & +++ & +++ & +++ \\
\hline A13 & P301L & 11 & IC-scFv235 & $2.23 \mathrm{E}+11$ & $252 \mathrm{~min}$ & ++++ & +++ & +++ & +++ & +++ & +++ & +++ & ++++ & +++ \\
\hline F6 & P301L & 3 & IC-scFv235 & $1.88 \mathrm{E}+11$ & $280 \mathrm{~min}$ & +++ & ++ & +++ & +++ & +++ & +++ & +++ & ++++ & +++ \\
\hline A50 & P301L & 9 & IC-6B2G12 & $1.16 \mathrm{E}+11$ & $291 \mathrm{~min}$ & +++ & +++ & +++ & +++ & ++ & +++ & +++ & +++ & +++ \\
\hline A52 & P301L & 9 & IC-6B2G12 & $1.23 \mathrm{E}+11$ & $235 \mathrm{~min}$ & +++ & +++ & +++ & +++ & +++ & +++ & +++ & +++ & +++ \\
\hline C1 & P301L & 7 & IC-6B2G12 & $2.20 E+11$ & Day 7 & ++ & ++++ & +++ & +++ & +++ & +++ & +++ & +++ & +++ \\
\hline B32 & htau/PS1 & 23 & IC-scFv235 & - & $120 \mathrm{~min}$ & +++ & +++ & +++ & +++ & +++ & +++ & +++ & ++++ & +++ \\
\hline A47 & htau/PS1 & 22 & IC-scFv235 & $1.40 E+11$ & $200 \mathrm{~min}$ & +++ & +++ & +++ & +++ & +++ & +++ & +++ & ++++ & +++ \\
\hline BB5 & htau/PS1 & 7 & IC-scFv235 & $2.56 \mathrm{E}+10$ & $200 \mathrm{~min}$ & + & 0 & 0 & 0 & 0 & 0 & 0 & 0 & 0 \\
\hline R1 & WT & 11 & IC-scFv235 & $4.36 \mathrm{E}+10$ & $125 \mathrm{~min}$ & + & 0 & 0 & 0 & 0 & 0 & 0 & 0 & 0 \\
\hline 4 & WT & 8 & IC-scFv235 & $1.34 \mathrm{E}+10$ & $265 \mathrm{~min}$ & + & 0 & 0 & 0 & 0 & 0 & 0 & 0 & 0 \\
\hline N32 & htau & 11 & IC-scFv235 & $3.87 \mathrm{E}+10$ & Day 7 & + & 0 & + & 0 & + & + & 0 & 0 & 0 \\
\hline A56 & htau/PS1 & 23 & IC-680 Dye & $7.45 \mathrm{E}+10$ & $122 \mathrm{~min}$ & + & ++ & 0 & 0 & 0 & 0 & 0 & 0 & 0 \\
\hline D24 & P301L & 7 & IC-680 Dye & $6.56 \mathrm{E}+10$ & $165 \mathrm{~min}$ & ++ & +++ & 0 & 0 & 0 & 0 & 0 & 0 & 0 \\
\hline 1 & WT & 8 & IC-6B2G12 & $1.22 \mathrm{E}+10$ & $290 \mathrm{~min}$ & + & 0 & 0 & 0 & 0 & 0 & 0 & 0 & 0 \\
\hline 2 & WT & 8 & IC-6B2G12 & $1.48 \mathrm{E}+10$ & $225 \mathrm{~min}$ & + & 0 & 0 & 0 & 0 & 0 & 0 & 0 & 0 \\
\hline 3 & WT & 8 & IC-6B2G12 & $1.21 E+10$ & $180 \mathrm{~min}$ & + & 0 & 0 & 0 & 0 & 0 & 0 & 0 & 0 \\
\hline A55 & P301L & 9 & IV-scFv235 & $2.07 E+11$ & Day 7 & ++ & +++ & ++++ & ++++ & +++ & +++ & +++ & +++ & +++ \\
\hline B11 & P301L & 13 & IV-scFv235 & $2.28 \mathrm{E}+11$ & Day 31 & + & +++ & ++++ & ++++ & +++ & +++ & +++ & +++ & +++ \\
\hline E19 & P301L & 8 & IV-scFv235 & $1.13 E+11$ & Day 7 & + & +++ & ++++ & ++++ & +++ & +++ & +++ & +++ & +++ \\
\hline A49 & P301L & 11 & IV-6B2G12 & $1.48 \mathrm{E}+11$ & Day 12 & ++ & +++ & ++++ & ++++ & ++ & +++ & +++ & +++ & +++ \\
\hline$C 2$ & P301L & 7 & IV-6B2G12 & $1.85 \mathrm{E}+11$ & Day 12 & ++ & +++ & ++++ & ++++ & ++ & +++ & +++ & +++ & +++ \\
\hline B15 & P301L & 13 & IV-6B2G12 & $7.62 \mathrm{E}+10$ & Day 31 & + & +++ & ++++ & ++++ & ++ & +++ & +++ & +++ & +++ \\
\hline VN139 & TgSwDI & 12 & IV-scFv235 & $1.58 \mathrm{E}+10$ & Day 31 & 0 & 0 & 0 & 0 & 0 & 0 & 0 & 0 & 0 \\
\hline 6 & WT & 8 & IV-scFv235 & $1.11 \mathrm{E}+10$ & Day 7 & + & 0 & 0 & 0 & 0 & 0 & 0 & 0 & 0 \\
\hline VN142A & TgSwDI & 12 & IV-6B2G12 & $1.49 \mathrm{E}+10$ & Day 31 & 0 & 0 & 0 & 0 & 0 & 0 & 0 & 0 & 0 \\
\hline 7 & WT & 8 & IV-6B2G12 & $8.95 \mathrm{E}+09$ & Day 7 & + & 0 & 0 & 0 & 0 & 0 & 0 & 0 & 0 \\
\hline D13 & P301L & 13 & IV-Control IgG & $8.94 \mathrm{E}+10$ & Day 16 & + & ++++ & 0 & 0 & 0 & - & - & - & - \\
\hline D15 & P301L & 13 & IV-Control IgG & $9.03 E+10$ & Day 16 & + & ++++ & 0 & 0 & 0 & - & - & - & - \\
\hline
\end{tabular}

Control IgG (P301L)
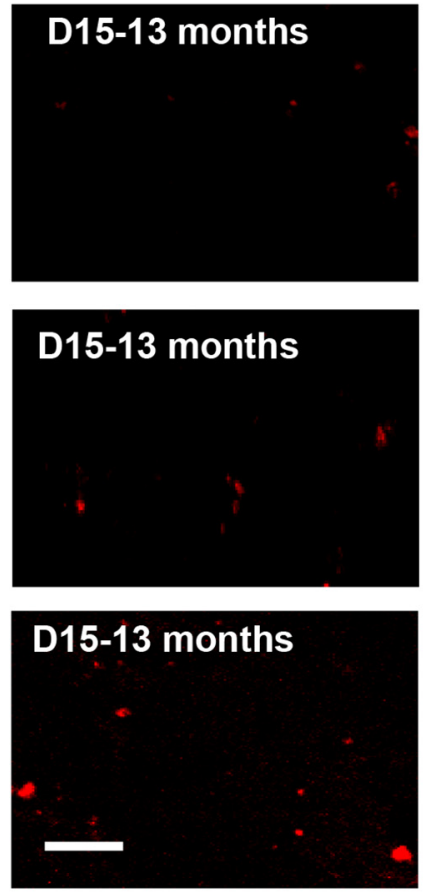
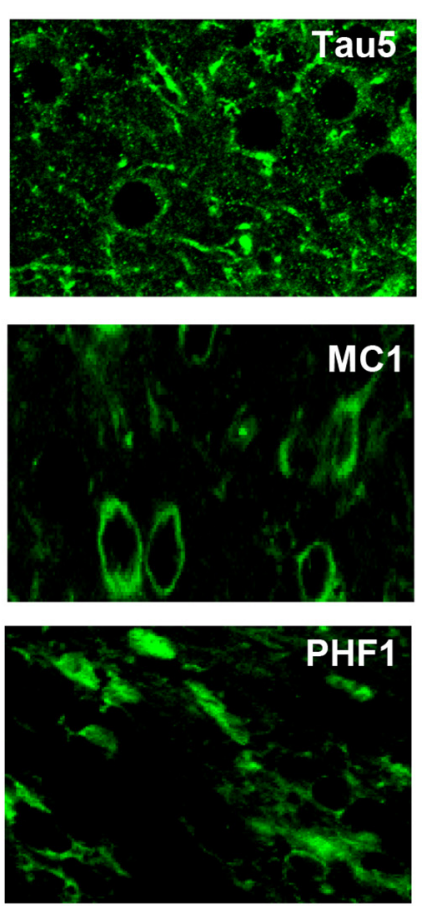

Merge
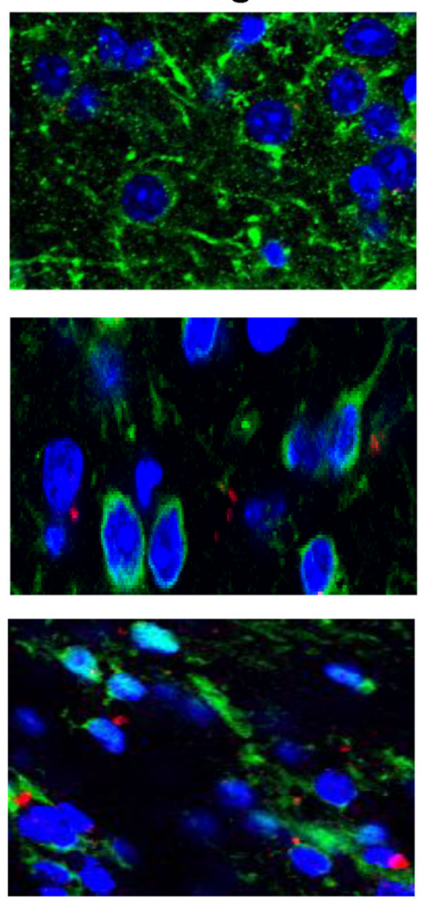

PDM
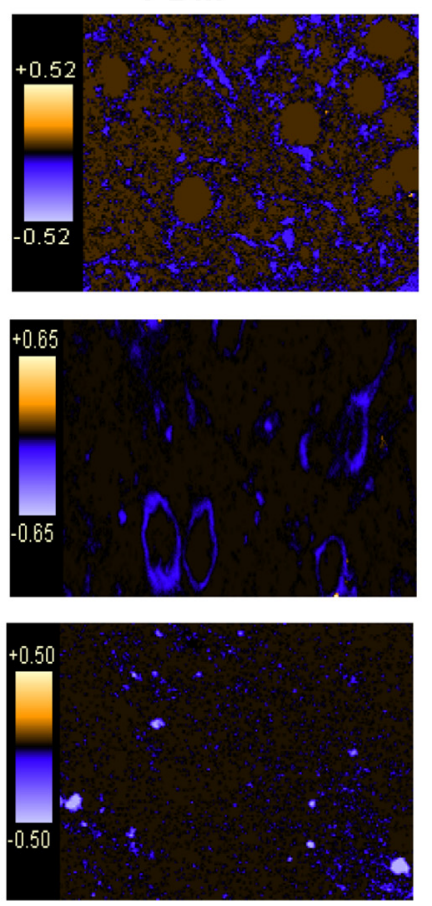

Figure 10. Brain sections from P301L mice injected with control lgG and stained with tau antibodies. P301L mice injected with control lgG showed some brain signal from the antibody, but it did not colocalize with the tau staining, indicating that these antibodies were getting into the brain of the P301L mice but were not binding to tau. Nuclei are stained blue with Hoechst nuclear stain and are shown in merged images. Scale bar, $10 \mu \mathrm{m}$. 
a

b

ScFv235 IVIS vs Brain tissue signal

6B2G12
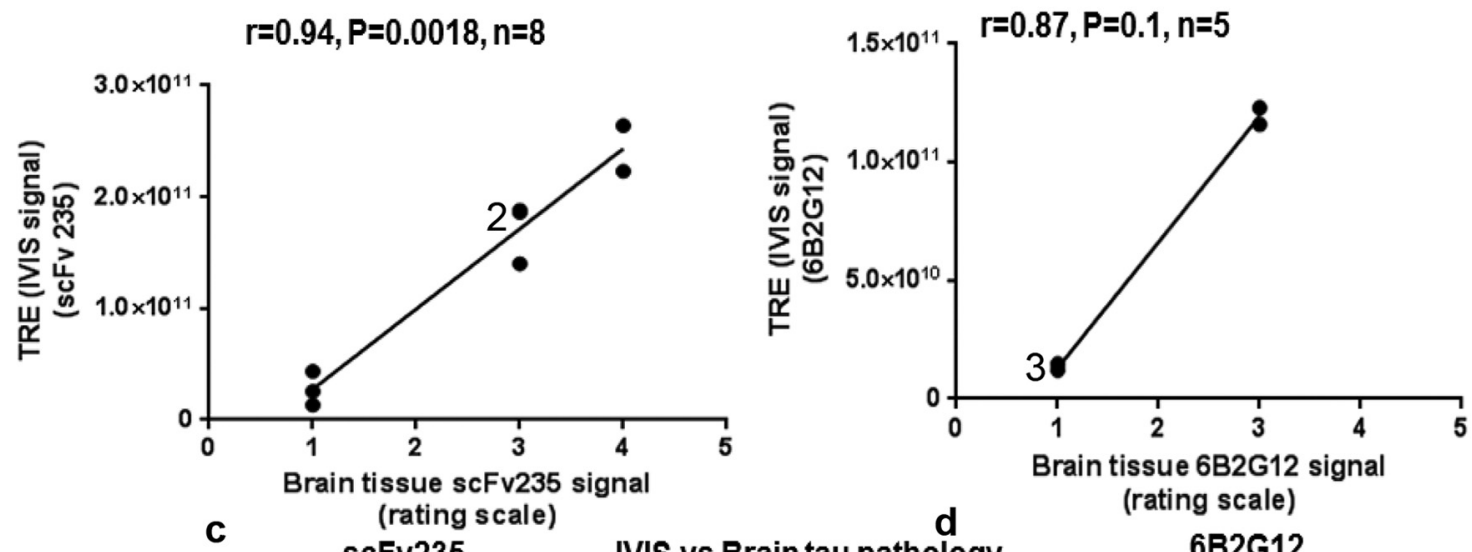

scFv235

d

(rating scale)

VIS vs Brain tau pathology
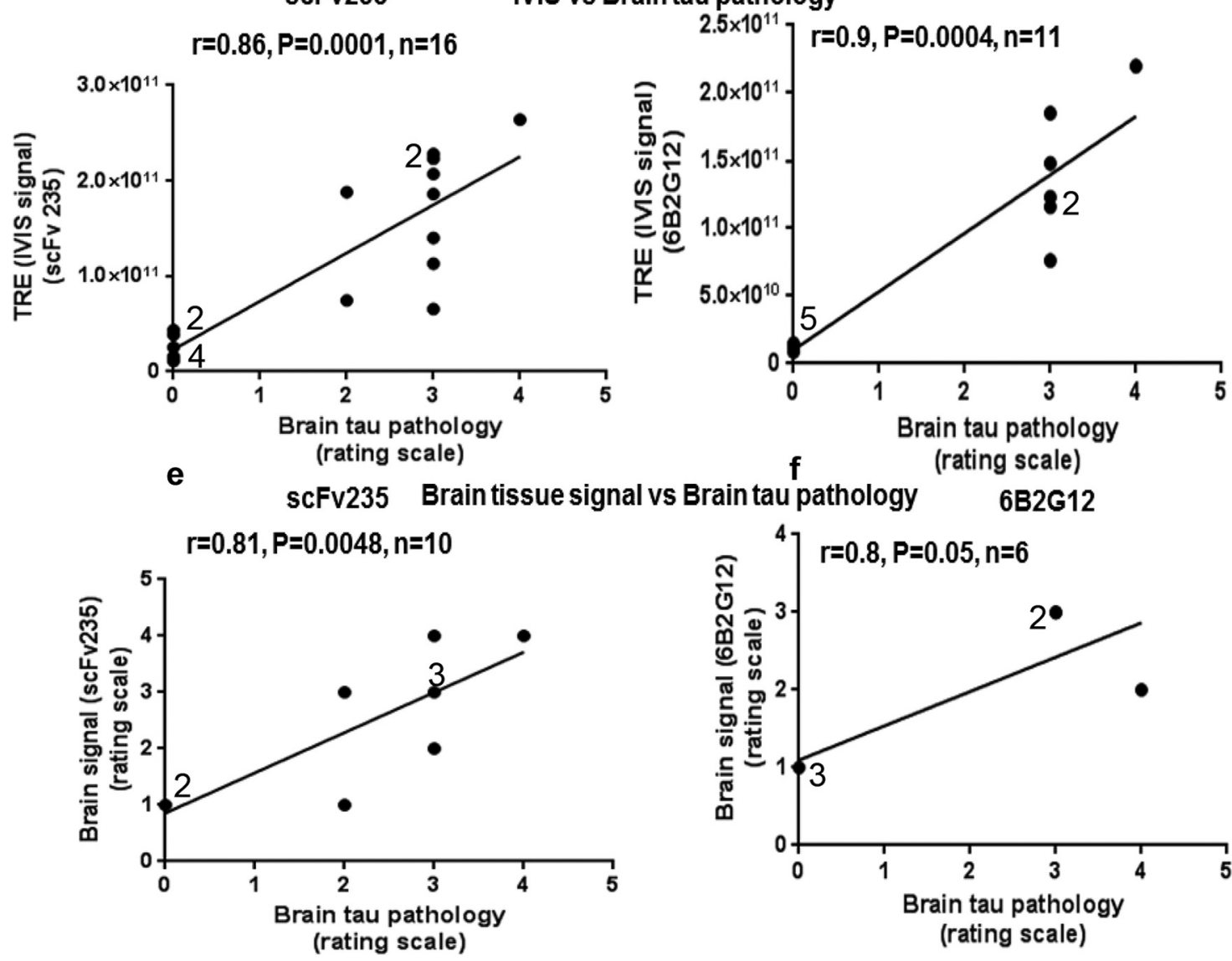

Figure 11. Correlation of IVIS signal, brain tissue probe signal, and tau pathology. $\boldsymbol{a}-\boldsymbol{f}$, Excellent correlation was observed of IVIS signal with brain tissue probe signal $(\boldsymbol{a}, \boldsymbol{b} ; \mathrm{scFv235:} r=0.94$,

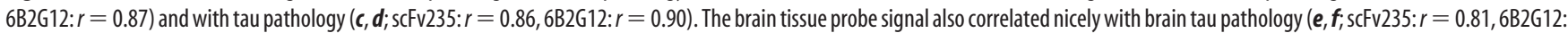
$r=0.80)$.

an efficient way to monitor the development of tau pathology and to screen for therapy-mediated clearance of tau aggregates, with each animal serving as its own control during longitudinal studies.

Our findings strongly support the promise of scFv's and/or tau antibodies to detect tau lesions in vivo. Future studies will determine whether similar effects can be obtained by targeting different tau epitopes and assess these ligands by PET imaging. In contrast to $\beta$-sheet-binding dyes, tau-antibody-derived probes targeting different epitopes can provide a detailed picture of the pathological profile of tau proteins in each individual. This information could then guide the treatment regimen, which may include tau immunotherapy targeting the same tau epitopes that were detected with imaging. Such a tailored approach is likely to be more efficacious to slow the progression of the tauopathy that is being targeted. Prior reports have clearly established the feasibility of moving tau-targeting immunotherapies into clinical trials (Asuni et al., 2007; Boimel et al., 2010; Boutajangout et al., 2010; Bi et al., 2011; Boutajangout et al., 2011; Chai et al., 2011; Kfoury et al., 2012; Troquier et al., 2012; Congdon et al., 2013; Gu 
et al., 2013; Theunis et al., 2013; Yanamandra et al., 2013; d'Abramo et al., 2013; Castillo-Carranza et al., 2014a; CastilloCarranza et al., 2014b). For these and other tau-targeting treatments being assessed in humans, it will be essential to employ selective biomarkers to determine target engagement, clearance, and disease progression to avoid the lengthy, expensive, and inconclusive studies in previous Alzheimer's $\mathrm{A} \beta$-targeting trials.

\section{References}

Andorfer C, Kress Y, Espinoza M, de Silva R, Tucker KL, Barde YA, Duff K, Davies P (2003) Hyperphosphorylation and aggregation of tau in mice expressing normal human tau isoforms. J Neurochem 86:582-590. CrossRef Medline

Asuni AA, Boutajangout A, Quartermain D, Sigurdsson EM (2007) Immunotherapy targeting pathological tau conformers in a tangle mouse model reduces brain pathology with associated functional improvements. J Neurosci 27:9115-9129. CrossRef Medline

Barbas CFI, Burton DR, Scott JK, Silverman GJ (2001) Phage display: a laboratory manual. New York: Cold Spring Harbor Laboratory.

Bi M, Ittner A, Ke YD, Götz J, Ittner LM (2011) Tau-targeted immunization impedes progression of neurofibrillary histopathology in aged P301L tau transgenic mice. PLoS One 6:e26860. CrossRef Medline

Blennow K, Hampel H, Weiner M, Zetterberg H (2010) Cerebrospinal fluid and plasma biomarkers in Alzheimer disease. Nat Rev Neurol 6:131-144. CrossRef Medline

Boimel M, Grigoriadis N, Lourbopoulos A, Haber E, Abramsky O, Rosenmann H (2010) Efficacy and safety of immunization with phosphorylated tau against neurofibrillary tangles in mice. Exp Neurol 224:472-485. CrossRef Medline

Boutajangout A, Quartermain D, Sigurdsson EM (2010) Immunotherapy targeting pathological tau prevents cognitive decline in a new tangle mouse model. J Neurosci 30:16559-16566. CrossRef Medline

Boutajangout A, Ingadottir J, Davies P, Sigurdsson EM (2011) Passive immunization targeting pathological phospho-tau protein in a mouse model reduces functional decline and clears tau aggregates from the brain. J Neurochem 118:658-667. CrossRef Medline

Castillo-Carranza DL, Gerson JE, Sengupta U, Guerrero-Muñoz MJ, Lasagna-Reeves CA, Kayed R (2014a) Specific targeting of tau oligomers in htau mice prevents cognitive impairment and tau toxicity following injection with brain-derived tau oligomeric seeds. J Alzheimers Dis 40: S97-S111. Medline

Castillo-Carranza DL, Sengupta U, Guerrero-Muñoz MJ, Lasagna-Reeves CA, Gerson JE, Singh G, Estes DM, Barrett AD, Dineley KT, Jackson GR, Kayed R (2014b) Passive immunization with tau oligomer monoclonal antibody reverses tauopathy phenotypes without affecting hyperphosphorylated neurofibrillary tangles. J Neurosci 34:4260-4272. CrossRef Medline

Chai X, Wu S, Murray TK, Kinley R, Cella CV, Sims H, Buckner N, Hanmer J, Davies P, O’Neill MJ, Hutton ML, Citron M (2011) Passive immunization with anti-Tau antibodies in two transgenic models: reduction of Tau pathology and delay of disease progression. J Biol Chem 286:3445734467. CrossRef Medline

Chien DT, Bahri S, Szardenings AK, Walsh JC, Mu F, Su MY, Shankle WR, Elizarov A, Kolb HC (2013) Early clinical PET imaging results with the novel PHF-tau radioligand [F-18]-T807. J Alzheimers Dis 34:457-468. CrossRef Medline

Chien DT, Szardenings AK, Bahri S, Walsh JC, Mu F, Xia C, Shankle WR, Lerner AJ, Su MY, Elizarov A, Kolb HC (2014) Early clinical PET imaging results with the novel PHF-tau radioligand [F18]-T808. J Alzheimers Dis 38:171-184. CrossRef Medline

Congdon EE, Gu J, Sait HB, Sigurdsson EM (2013) Antibody uptake into neurons occurs primarily via clathrin-dependent Fcgamma receptor endocytosis and is a prerequisite for acute tau protein clearance. J Biol Chem 288:35452-35465. CrossRef Medline

Congdon EE, Krishnaswamy S, Sigurdsson EM (2014) Harnessing the immune system for treatment and detection of tau pathology. J Alzheimers Dis 40:S113-S121. CrossRef Medline

d'Abramo C, Acker CM, Jimenez HT, Davies P (2013) Tau passive immunotherapy in mutant P301L mice: antibody affinity versus specificity. PLoS One 8:e62402. CrossRef Medline

Davis J, Xu F, Deane R, Romanov G, Previti ML, Zeigler K, Zlokovic BV, Van
Nostrand WE (2004) Early-onset and robust cerebral microvascular accumulation of amyloid beta-protein in transgenic mice expressing low levels of a vasculotropic Dutch/Iowa mutant form of amyloid betaprotein precursor. J Biol Chem 279:20296-20306. CrossRef Medline

Fodero-Tavoletti MT, Okamura N, Furumoto S, Mulligan RS, Connor AR, McLean CA, Cao D, Rigopoulos A, Cartwright GA, O’Keefe G, Gong S, Adlard PA, Barnham KJ, Rowe CC, Masters CL, Kudo Y, Cappai R, Yanai K, Villemagne VL (2011) 18F-THK523: a novel in vivo tau imaging ligand for Alzheimer's disease. Brain 134:1089-1100. CrossRef Medline

Fodero-Tavoletti MT, Furumoto S, Taylor L, McLean CA, Mulligan RS, Birchall I, Harada R, Masters CL, Yanai K, Kudo Y, Rowe CC, Okamura N, Villemagne VL (2014) Assessing THK523 selectivity for tau deposits in Alzheimer's disease and non Alzheimer's disease tauopathies. Alzheimers Res Ther 6:11. CrossRef Medline

Gu J, Congdon EE, Sigurdsson EM (2013) Two novel Tau antibodies targeting the 396/404 region are primarily taken up by neurons and reduce Tau protein pathology. J Biol Chem 288:33081-33095. CrossRef Medline

Hales CM, Hu WT (2013) From frontotemporal lobar degeneration pathology to frontotemporal lobar degeneration biomarkers. Int Rev Psychiatry 25:210-220. CrossRef Medline

Harada R, Okamura N, Furumoto S, Tago T, Maruyama M, Higuchi M, Yoshikawa T, Arai H, Iwata R, Kudo Y, Yanai K (2013) Comparison of the binding characteristics of [18F]THK-523 and other amyloid imaging tracers to Alzheimer's disease pathology. Eur J Nucl Med Mol Imaging 40:125-132. CrossRef Medline

Kaur S, Venktaraman G, Jain M, Senapati S, Garg PK, Batra SK (2012) Recent trends in antibody-based oncologic imaging. Cancer Lett 315:97111. CrossRef Medline

Kfoury N, Holmes BB, Jiang H, Holtzman DM, Diamond MI (2012) Transcellular propagation of tau aggregation by fibrillar species. J Biol Chem 287:19440-19451. CrossRef Medline

Krishnamurthy PK, Deng Y, Sigurdsson EM (2011) Mechanistic studies of antibody-mediated clearance of tau aggregates using an ex vivo brain slice model. Front Psychiatry 2:59. CrossRef Medline

Krishnaswamy S, Kabir ME, Miyamoto M, Furuichi Y, Komiyama T (2009) Cloning antifungal single chain fragment variable antibodies by phage display and competitive panning elution. Anal Biochem 395:16-24. CrossRef Medline

Krishnaswamy S, Kabir ME, Rahman MM, Miyamoto M, Furuichi Y, Komiyama T (2011) Isolation and characterization of recombinant single chain fragment variable anti-idiotypic antibody specific to Aspergillus fumigatus membrane protein. J Immunol Methods 366:60-68. CrossRef Medline

Lemere CA, Masliah E (2010) Can Alzheimer disease be prevented by amyloid-beta immunotherapy? Nat Rev Neurol 6:108-119. CrossRef Medline

Lewis J, McGowan E, Rockwood J, Melrose H, Nacharaju P, Van Slegtenhorst M, Gwinn-Hardy K, Paul Murphy M, Baker M, Yu X, Duff K, Hardy J, Corral A, Lin WL, Yen SH, Dickson DW, Davies P, Hutton M (2000) Neurofibrillary tangles, amyotrophy and progressive motor disturbance in mice expressing mutant (P301L) tau protein. Nat Genet 25:402-405. CrossRef Medline

Li Q, Lau A, Morris TJ, Guo L, Fordyce CB, Stanley EF (2004) A syntaxin 1, Galpha(o), and $N$-type calcium channel complex at a presynaptic nerve terminal: analysis by quantitative immunocolocalization. J Neurosci 24: 4070-4081. CrossRef Medline

Maruyama M, Shimada H, Suhara T, Shinotoh H, Ji B, Maeda J, Zhang MR, Trojanowski JQ, Lee VM, Ono M, Masamoto K, Takano H, Sahara N, Iwata N, Okamura N, Furumoto S, Kudo Y, Chang Q, Saido TC, Takashima A, Lewis J, Jang MK, Aoki I, Ito H, Higuchi M (2013) Imaging of tau pathology in a tauopathy mouse model and in Alzheimer patients compared to normal controls. Neuron 79:1094-1108. CrossRef Medline

Mason NS, Mathis CA, Klunk WE (2013) Positron emission tomography radioligands for in vivo imaging of Abeta plaques. J Labelled Comp Radiopharm 56:89-95. CrossRef Medline

Nelson PT, Alafuzoff I, Bigio EH, Bouras C, Braak H, Cairns NJ, Castellani RJ, Crain BJ, Davies P, Del Tredici K, Duyckaerts C, Frosch MP, Haroutunian V, Hof PR, Hulette CM, Hyman BT, Iwatsubo T, Jellinger KA, Jicha GA, Kövari E, Kukull WA, Leverenz JB, Love S, Mackenzie IR, Mann DM, Masliah E, McKee AC, Montine TJ, Morris JC, Schneider JA, Sonnen JA, Thal DR, Trojanowski JQ, Troncoso JC, Wisniewski T, Woltjer RL, Beach 
TG (2012) Correlation of Alzheimer disease neuropathologic changes with cognitive status: a review of the literature. J Neuropathol Exp Neurol 71:362-381. CrossRef Medline

Okamura N, Suemoto T, Furumoto S, Suzuki M, Shimadzu H, Akatsu H, Yamamoto T, Fujiwara H, Nemoto M, Maruyama M, Arai H, Yanai K, Sawada T, Kudo Y (2005) Quinoline and benzimidazole derivatives: candidate probes for in vivo imaging of tau pathology in Alzheimer's disease. J Neurosci 25:10857-10862. CrossRef Medline

Okamura N, Furumoto S, Fodero-Tavoletti MT, Mulligan RS, Harada R, Yates P, Pejoska S, Kudo Y, Masters CL, Yanai K, Rowe CC, Villemagne VL (2014) Non-invasive assessment of Alzheimer's disease neurofibrillary pathology using 18F-THK5105 PET. Brain 137:1762-1771. CrossRef Medline

Olafsen T, Wu AM (2010) Antibody vectors for imaging. Semin Nucl Med 40:167-181. CrossRef Medline

Ono M, Hayashi S, Matsumura K, Kimura H, Okamoto Y, Ihara M, Takahashi R, Mori H, Saji H (2011) Rhodanine and thiohydantoin derivatives for detecting tau pathology in Alzheimer's brains. ACS Chem Neurosci 2:269-275. CrossRef Medline

Theunis C, Crespo-Biel N, Gafner V, Pihlgren M, López-Deber MP, Reis P, Hickman DT, Adolfsson O, Chuard N, Ndao DM, Borghgraef P, Devijver H, van LF, Pfeifer A, Muhs A (2013) Efficacy and safety of a liposomebased vaccine against protein Tau, assessed in tau.P301L mice that model tauopathy. PLoS One 8:e72301. CrossRef Medline

Troquier L, Caillierez R, Burnouf S, Fernandez-Gomez FJ, Grosjean ME, Zommer N, Sergeant N, Schraen-Maschke S, Blum D, Buee L (2012) Targeting phospho-Ser422 by active Tau immunotherapy in the THY-
Tau22 mouse model: a suitable therapeutic approach. Curr Alzheimer Res 9:397-405. CrossRef Medline

Villemagne VL, Furumoto S, Fodero-Tavoletti MT, Mulligan RS, Hodges J, Harada R, Yates P, Piguet O, Pejoska S, Doré V, Yanai K, Masters CL, Kudo Y, Rowe CC, Okamura N (2014) In vivo evaluation of a novel tau imaging tracer for Alzheimer's disease. Eur J Nucl Med Mol Imaging 41:816-826. CrossRef Medline

Weiner MW, Veitch DP, Aisen PS, Beckett LA, Cairns NJ, Green RC, Harvey D, Jack CR, Jagust W, Liu E, Morris JC, Petersen RC, Saykin AJ, Schmidt ME, Shaw L, Shen L, Siuciak JA, Soares H, Toga AW, Trojanowski JQ; Alzheimer's Disease Neuroimaging Initiative (2013) The Alzheimer's Disease Neuroimaging Initiative: a review of papers published since its inception. Alzheimers Dement 9:e111-e194. CrossRef Medline

Xia CF, Arteaga J, Chen G, Gangadharmath U, Gomez LF, Kasi D, Lam C, Liang Q, Liu C, Mocharla VP, Mu F, Sinha A, Su H, Szardenings AK, Walsh JC, Wang E, Yu C, Zhang W, Zhao T, Kolb HC (2013) [(18)F]T807, a novel tau positron emission tomography imaging agent for Alzheimer's disease. Alzheimers Dement 9:666-676. CrossRef Medline

Yanamandra K, Kfoury N, Jiang H, Mahan TE, Ma S, Maloney SE, Wozniak DF, Diamond MI, Holtzman DM (2013) Anti-tau antibodies that block tau aggregate seeding in vitro markedly decrease pathology and improve cognition in vivo. Neuron 80:402-414. CrossRef Medline

Zhang W, Arteaga J, Cashion DK, Chen G, Gangadharmath U, Gomez LF, Kasi D, Lam C, Liang Q, Liu C, Mocharla VP, Mu F, Sinha A, Szardenings AK, Wang E, Walsh JC, Xia C, Yu C, Zhao T, Kolb HC (2012) A highly selective and specific PET tracer for imaging of Tau pathologies. J Alzheimers Dis 31:601-612. CrossRef Medline 